\title{
プレキャスト部材間の新鉄筋継手構造における 耐荷性に関する実験的研究
}

\author{
北村 健 1 ・趙 唯堅 $2 \cdot$ 細谷 学 3 ・岩城 一郎 4 \\ 1 正会員 大成建設株式会社 土木本部土木技術部（†163-0606 東京都新宿区西新宿 1-25-1） \\ E-mail:ktmtks00@pub.taisei.co.jp \\ 2 フェロー会員 大成建設株式会社 技術センター都市基盤技術研究部 \\ （干245-0051＼cjkstart神奈川県横浜市戸塚区名瀬町 344-1） \\ E-mail: zhao@sakura.taisei.co.jp \\ 3 正会員 大成建設株式会社 土木本部土木技術部（干163-0606 東京都新宿区西新宿 1-25-1） \\ E-mail: manabu.hosotani@sakura.taisei.co.jp \\ 4 フェロー会員 日本大学教授 工学部土木工学科（干963-8642 福島県郡山市田村町徳定字中河原 1) \\ E-mail: iwaki@civil.ce.nihon-u.ac.jp
}

\begin{abstract}
プレキャスト(以下，PCa)構造の施工を行う際，PCa 部材同士の接合作業に手間を要したり，接合部が構 造的な弱部となる懸念がある。そこで，接合に関する 2 種類の新鉄筋継手を考案した。これらの構造は, 接合部の両側の PCa 部材から鉄筋を突出させ，その鉄筋先端には事前にお互いが噛み合う構造の鋼製治具 を接合させておき，部材設置後に鋼製治具の周囲に高性能な間詰め材を充填し一体化を図るものである. 継手性能の検証として, 鉄筋継手 1 組を対象とした接合部の試験体を用いて引張試験を実施し, 更に, PCa 構造の一例として道路橋 PCa 床版を想定し, 面部材の試験体を用いて静的載荷試験を実施した。 その 結果， 2 種類の継手構造のうち, 継手構造 $\mathrm{B}$ ( $\mathrm{C}$ 型, $\mathrm{T}$ 型の治具を嵌合 (かん合) する形式)は, 十分な耐 荷性能を示すことが確認された。
\end{abstract}

Key Words : RC joint, precast, rebar connection system, fiber reinforced mortar

\section{1. はじめに}

昨今，少子高齢化による建設労働人口の減少に伴い， 建設業では今後の社会インフラの構築や維持管理に対す る担い手が不足することが喫緊の課題である. そのため, 労働環境の改善による将来の担い手確保とともに, より

一層の生産性の向上が求められている.

生産性の向上に関しては，国土交通省を中心に iConstruction が推進されており，土工事に対しては ICT の 活用による機械化施工などの対策が徐々に進められてい る 1). 一方，躯体構築工事でもプレキャス卜（以下， PCa）部材の活用をはじめ，PCa 部材の大型化や規格化 などが方向性として示されている ${ }^{2}$. このような $\mathrm{PCa}$ 部 材の適用メリットは，部材を工場で製作するため，現場 施工の場合と比べ製作時の環境の変化や品質のばらつき が小さく安定した品質で部材を製作できること，また， PCa 部材で置き換えられる箇所の鉄筋加工・組立，型枠 作業，コンクリートの打込み，養生など現場での作業量
を縮減できるため，全体として施工効率を高め，生産性 の向上に繋がること, とされている.

しかしながら，PCa 構造の施工を行う場合，PCa 部材 同士の接合部があり，その接合形式によっては現場での 接合作業が煩雑となったり, 熟練した技能を必要とする 場合も多い，そのため，PCa 部材よりも接合部の施工品 質が問題となって構造物全体における弱部となる可能性 も否めない.

そこで，PCa 部材の接合構造を出来るだけコンパクト かつ簡略化することにより接合部の施工量を縮小化し現 場施工の省力化を目指しつつ，技能不足等による品質低 下リスクを減らし，更に，高品質な間詰め材を適用する ことによる接合部の高耐久化を実現することが肝要であ る. 本研究は，このようなコンセプトに基づき，PCa 部 材間に新しい鉄筋継手を使用した接合構造の開発を目指 すものである. 


\section{2. 鉄筋の継手構造}

\section{(1) 既往のPCa 部材間の接合と懸念事項}

既往の $\mathrm{PCa}$ 部材間の接合形式を整理すると以下の $3 つ$ に分類される. これを図-1に示す.

1 つ目は，接合部に両側の PCa 部材から突出した鉄筋 を接合部のコンクリートに定着もしくは接合部のコンク リートとの付着を介した鉄筋同士の継手である．代表的 な形式には重亦継手 3)やループ継手 4)5等が挙げられる. これらの継手は, 継手性能による寸法上の制約から, $\mathrm{PCa}$ 部材間の接合部に $400 \sim 500 \mathrm{~mm}$ 以上の幅が必要であ ったが，近年，接合部の幅を縮小寸る方向に開発・実用 化されつつある 9,。しかしながら，接合部の幅は依然 として $300 \mathrm{~mm}$ 程度と大きく, 現場施工の省力化へのメ リットが減るとともに，施工による品質低下リスクも増 えることが懸念される.

2 つ目は，鉄筋同士を結合寸る形式のものであり，代 表的なものに溶接継手 ${ }^{8)}$ や機械式継手 ${ }^{8)}$ がある. 溶接継 手には突合せアーク溶接継手等があり，また，機械式継 手には，ねじふし鉄筋継手およびモルタル充てん継手等 がある.これらの鉄筋継手は PCa 部材一の適用は可能 であるが，接合部の断面が大きく配置される鉄筋継手が 多くなると, 溶接継手では, 結合する鉄筋配置のずれや 開先間隔の調整に手間を要するだけでなく, 溶接作業に も時間を要すること，また，機械式継手では，継手箇所 での鉄筋配置にズレが生じ継手が困難となったり，配置 できても継手へのグラウトやモルタルの充てんやトルク 固定等の作業に手間を要することが懸念される.

最後に PCa 部材同士を直接的に接合する形式である. この形式には，コッタ式継手 9,10,111等がある.これは, $\mathrm{PCa}$ 部材の鉄筋とは別に, $\mathrm{PCa}$ 部材の接合面に $\mathrm{C}$ 型の金 物を埋め込んで製作し，設置後，接合箇所再側の $\mathrm{C}$ 型 の金物にクサビ状の $\mathrm{H}$ 型の金物を差し込むことにより 連結する構造である.この形式では，PCa 部材端部の接 合面付近に PCa 部材の鉄筋や接合用の金物が比較的過 密に配置された状態となり $\mathrm{PCa}$ 部材製作時の品質低下 リスクが増えたり，施工時には $\mathrm{C}$ 型金物の製作精度の 誤差があってもクサビを押込むことにより固定するため, 金物周辺に初期応力が発生する懸念がある.

\section{(2) 新継手構造の概要}

新継手構造のコンセプトとして，“現場での接合作業 が簡単で手間が掛からない, かつ, 安定した品質を確保 できる”こととした．また，実施方法として次のように 考えた. まず，PCa 部材の製作段階で，施工時の接合部 の両側に配置される $\mathrm{PCa}$ 部材の端部から鉄筋を突出さ せておき，かつ，それらの先端に，PCa 部材設置時にお 互いが所定のクリアランスを有した状態で嵌合（かん

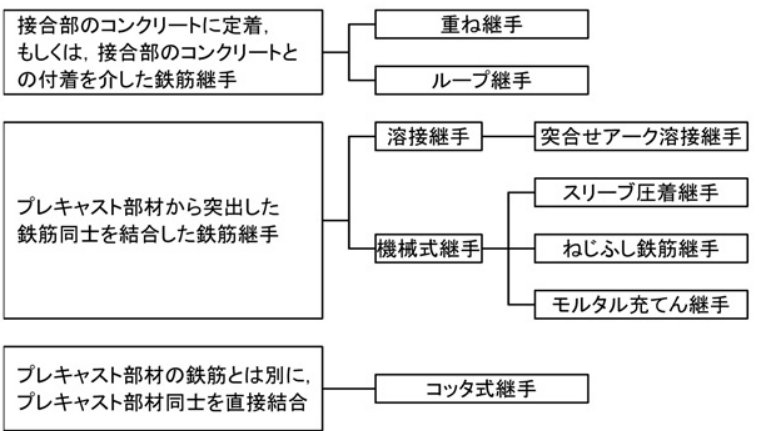

図-1 プレキャスト部材間の接合方法例

合）可能な特殊な先端治具を結合しておく. 現場搬入後, 先端治具を嵌合させるように PCa 部材を配置し, 先端 治具周囲を高性能な間詰め材を使用して一括で打込み・ 養生するのみで，接合作業を完了させる，なお，先端治 具を嵌合した際の治具同士のクリアランスが小さいため, 接合部の間詰め材は補强繊維を混入した無収縮モルタル を使用する。

このような概念で, 次の $2 つ の$ 継手構造を検討した.

\section{a) 継手構造 $A$}

図-2 のように, 先端冶具に最もシンプルな形状のプ レート部材（以下，P 型治具と記載）を適用した継手で ある. P 型治具を介して鉄筋を接合するため, 対向する 鉄筋同士は同一直線状での配置でなく, 若干偏心した状 態となる. また, $\mathrm{P}$ 型治具は対向する鉄筋が通過する部 分は切り欠きを設けている。 なお，本構造は，図-3の ように PCa 部材の左右への移動によりお互いの治具を 嵌合させることができる.

\section{b) 継手構造 $B$}

図-4のように，片方の鉄筋先端には矩形もしくは円 形のプレート（以下， $\mathrm{T}$ 型治具と記載）を取付け，他方 の鉄筋には先のプレートを包み込むような形状の治具

(以下， C 型冶具と記載）を取付けた継手である. 本構 造は, 2 種類の先端冶具自体が勘合する構造となってお り，対向する鉄筋同士は一直線上に配置され偏心がない， なお，本構造では，図-5 のように PCa 部材の上下への 移動によりお互いの治具を嵌合させることができる.

\section{(3) 新継手の特徵と今後の展望}

省力化の観点では, 既往の接合方法の重齐継手やルー プ継手に比べると嵌合する先端治具の配置可能な $100 \mathrm{~mm}$ 程度に縮小寸ることができる上, 間詰め材に纎 維補強モルタルを使用するため，打設手間が少なくなる だけでなく，PCa 部材の端部に鉄筋を配置するのみで接 合部内の配筋を省略できる可能性がある．また，機械式 継手に比べるとナット締付作業, トルク管理や充填作業 が不要となるメリットは考えられる.ただし, 新継手で は先端治具同士のクリアランスが小さいため $\mathrm{PCa}$ 部材 


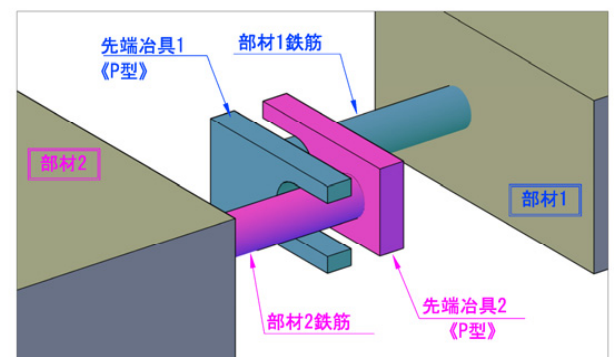

図-2 継手構造 $\mathrm{A}$ の先端治具

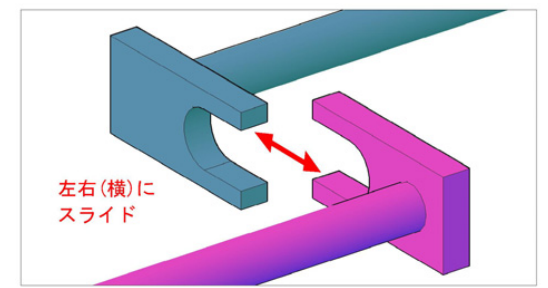

図-3 設置イメージ図（継手構造 A）

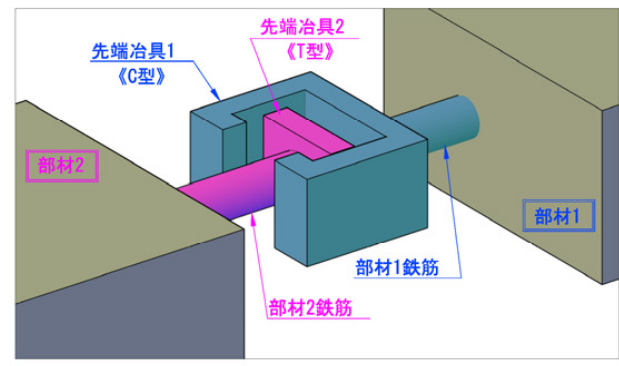

図-4 継手構造 B の先端治具

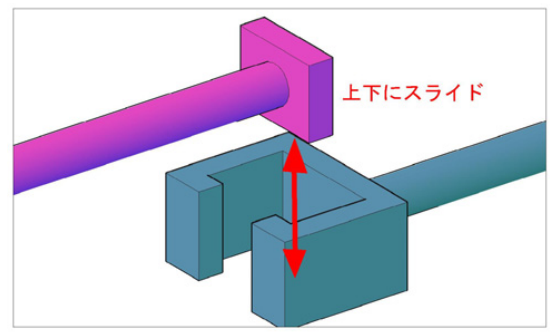

図-5 設置イメージ図（継手構造 B）

が効率良く設置できるかは不透明であり別途施工試験等 を行い，施工性の確認が必要である，次に，品質低下リ スクの削減の観点では，前述のように接合部の幅を縮小 し，高性能な間詰材を適用寸ることで品質リスクを低減 し，また，コッタ式継手のように接合部周辺に初期応力 を生じさせる可能性もない，最後に，耐久性の観点では, 接合部に高性能な間詰材（繊維補強モルタル）を適用す ることにより，ひび割れ低減効果があり，劣化因子の侵 入抵抗性が高まることが期待できる.

本論文では，新継手構造の耐荷性能を確認するため, 継手単体の引張試験や道路橋床版を想定した版部材に適 用した場合の静的載荷試験の結果について記載する.

\section{3. 継手単体の引張試験}

新継手構造を道路橋 PCa 床版に適用寸る場合, 活荷
表-1 引張試験の各シリーズの着目点

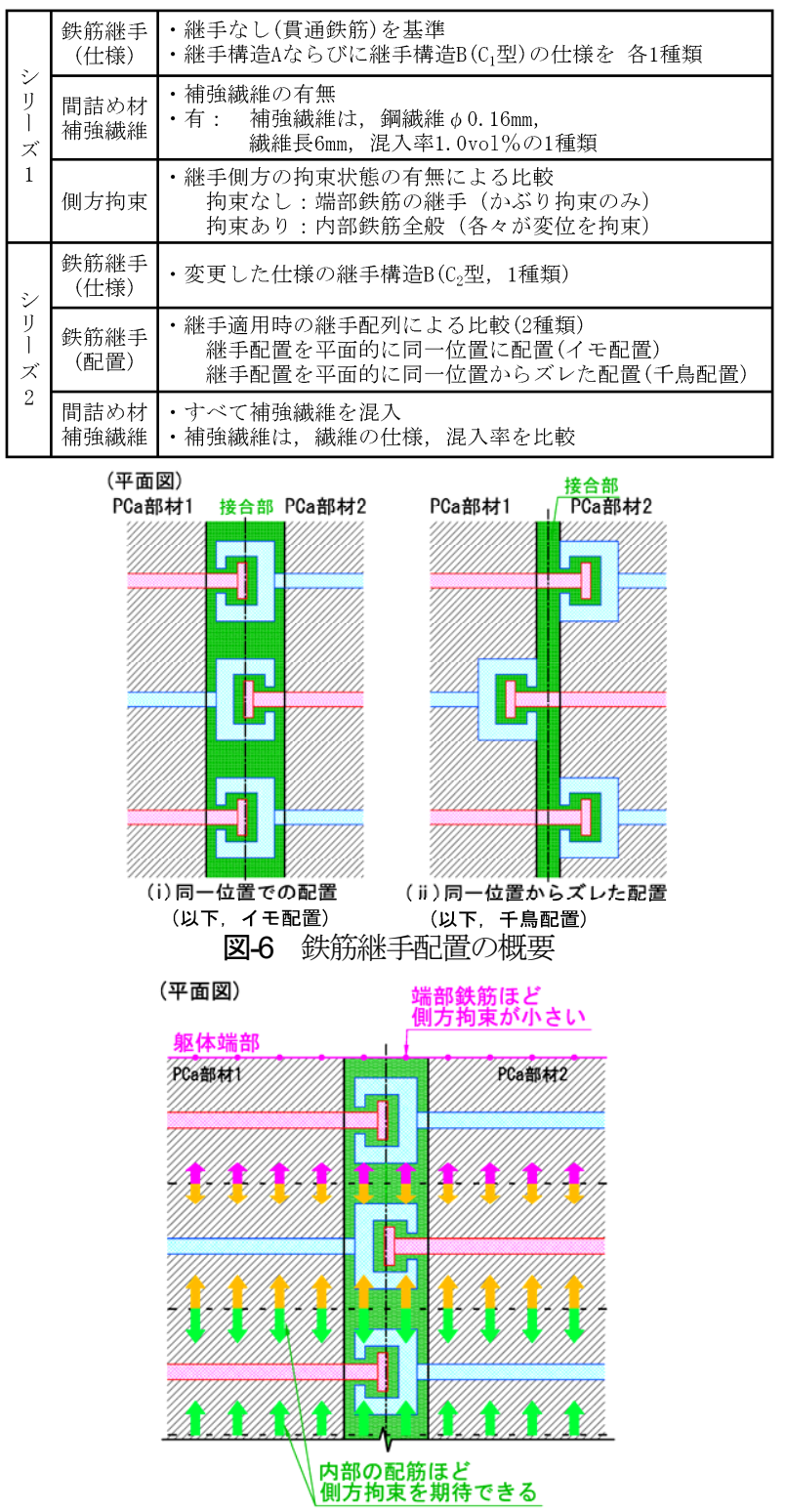

図-7 継手箇所の側方拘束

重等の作用による曲げ引張が主な作用状態となる. そこ で，各継手構造（継手構造 $\mathrm{A}$ および B)の而荷機構なら びに静的引張耐力を確認するために，1組の鉄筋継手を 有する形状で切り出した接合部の試験体を製作し，引張 試験を行った.

\section{(1) 試験ケース}

本継手は，間詰め材を介して 2 本の鉄筋を一体化させ る構造である. そのため, 継手性能に影響を及ぼす要素 として, 先端治具の仕様, 継手の配置（図-6 参照）, 間詰め材の強度や補強䋊維の仕様，継手箇所の側方の拘 束状態 (PCa 部材内の治具配置により拘束が異なる. 最 外縁鉄筋 : 小, 中央鉄筋 : 大 等の配置条件によるもの, 図-7 参照) が考えられる. そこで，表-1 に示寸項目に 着目し, シリーズ 1 は, 継手構造の成立性の検証, シリ 
(平面図)

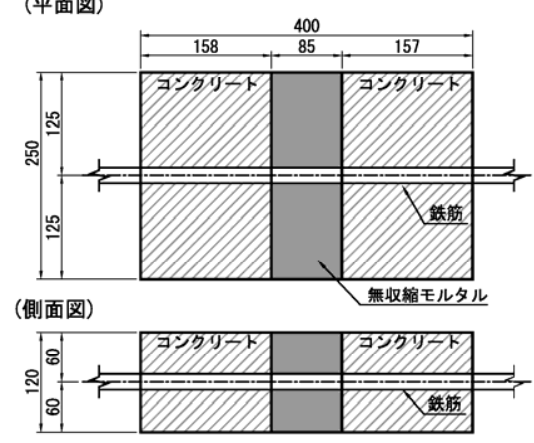

(i) 貫通鉄筋
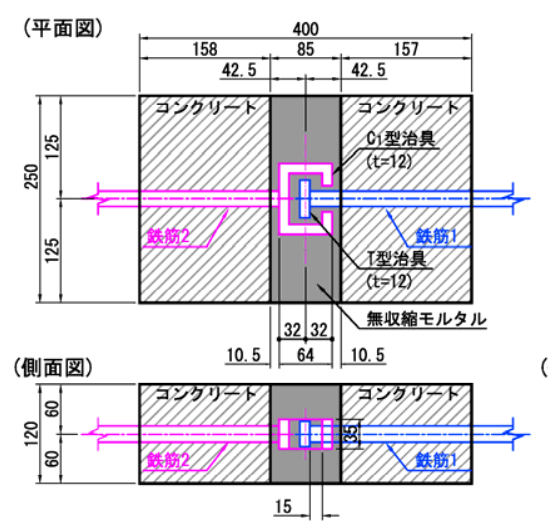

(iii) 継手構造 $B\left(C_{1}\right.$ 型)-イモ配置
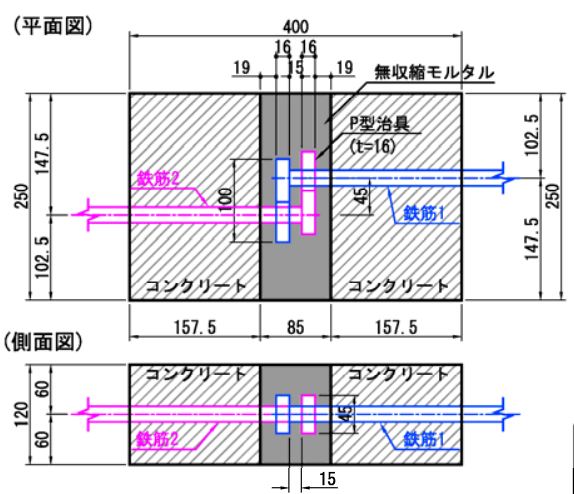

(ii) 継手構造A

(平面図)
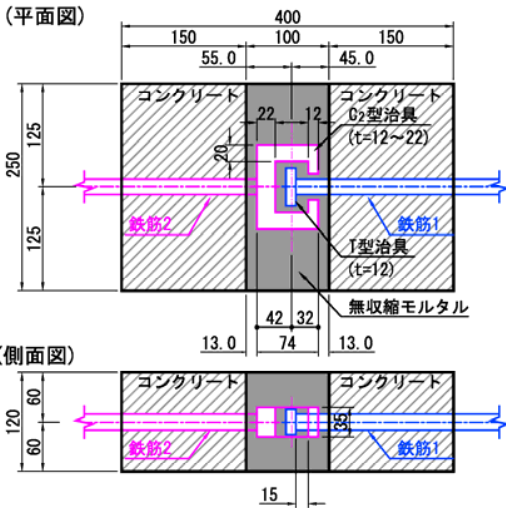

(iv) 継手構造 $\mathrm{B}\left(\mathrm{C}_{2}\right.$ 型) -イモ配置

図-8 引張試験 試験体形状図
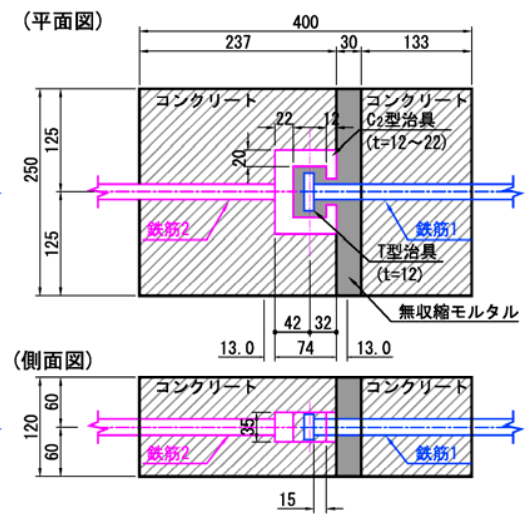

( v) 継手構造 $B\left(C_{2}\right.$ 型)-千鳥配置
表-2 引張試験 試験ケース一覧表

\begin{tabular}{|c|c|c|c|c|c|c|c|c|c|c|}
\hline \multirow{2}{*}{\multicolumn{2}{|c|}{ 実験ケース }} & \multicolumn{4}{|c|}{ 継手仕様 } & \multirow{2}{*}{$\begin{array}{l}\text { 継手 } \\
\text { 配置 }\end{array}$} & \multicolumn{3}{|c|}{ 接合部の補強繊維 } & \multirow[b]{2}{*}{$\begin{array}{l}\text { 側方 } \\
\text { 拘束 }\end{array}$} \\
\hline & & \multirow{2}{*}{$\begin{array}{c}\begin{array}{c}\text { 継手 } \\
\text { 形式 }\end{array} \\
\text { 貫通鉄筋 }\end{array}$} & \multicolumn{3}{|c|}{\begin{tabular}{|c} 
先端治具 \\
タイプ
\end{tabular}} & & $\begin{array}{l}\text { 繊維 } \\
\text { 種類 } \\
\end{array}$ & $\begin{array}{c}\text { 纎維長 } \\
(\mathrm{mm}) \\
\end{array}$ & $\begin{array}{c}\text { 混入率 } \\
(\%)\end{array}$ & \\
\hline \multirow{7}{*}{$\begin{array}{l}シ 1 \\
\text { リ } \\
1 \\
\text { X゙ } \\
1\end{array}$} & CASE1 & & & - & & （貫通） & 鋼瀻維 & 6 & 1 & 無 \\
\hline & CASE2 & 継手A & P型 & $-P$ & P型 & (イモ) & \multicolumn{3}{|c|}{ 無 } & 有 \\
\hline & CASE3 & 継手A & P型 & $-\mathrm{F}$ & P型 & (イモ) & 鋼瀻維 & 6 & 1 & 有 \\
\hline & CASE 4 & 継手A & P型 & $-\mathrm{F}$ & P型 & (イモ) & 鋼瀻維 & 6 & 1 & 無 \\
\hline & CASE5 & 継手B & $\mathrm{C}_{1}$ 型 & -1 & T型 & イモ & \multicolumn{3}{|c|}{ 無 } & 有 \\
\hline & CASE6 & 継手B & $\mathrm{C}_{1}$ 型 & -1 & T型 & イモ & 鋼緎維 & 6 & 1 & 有 \\
\hline & CASE7 & 継手B & $\mathrm{C}_{1}$ 型 & -1 & T型 & イモ & 鋼緎維 & 6 & 1 & 無 \\
\hline \multirow{5}{*}{$\begin{array}{l}シ \\
y \\
1 \\
\text { X゙ } \\
2\end{array}$} & CASE 8 & 継手B & $\mathrm{C}_{2}$ 型 & -1 & T型 & イモ & 鋼繊維 & 6 & 1 & 有 \\
\hline & CASE9 & 継手B & $\mathrm{C}_{2}$ 型 & -1 & T型 & イモ & 鋼繊維 & 6 & 1.5 & 有 \\
\hline & CASE10 & 継手B & $\mathrm{C}_{2}$ 型 & -1 & T型 & イモ & 鋼繊維 & 9 & 1 & 有 \\
\hline & CASE11 & 継手B & $\mathrm{C}_{2}$ 型 & -1 & T型 & イモ & 有機繊維 & 12 & 1.5 & 有 \\
\hline & CASE12 & 継手B & $\mathrm{C}_{2}$ 型 & -1 & T型 & 千鳥 & 鋼繊維 & 6 & 1 & 有 \\
\hline
\end{tabular}

一ズ 2 は，継手仕様の決定を目的として段階的に試験を 実施した. なお，継手構造 B における C 型治具の仕様 は，シリーズ移行の際に， $\mathrm{C}_{1}$ 型治具（部材厚一律 $12 \mathrm{~mm}$, 材質を SM490）から C 2 型治具（部材厚 12～22mm，材質 を SM570）に変更した. 実施ケース一覧を表-2 に示す.

\section{(2) 試験体の概要}

試験体の形状寸法を図-8 に示す。なお，鉄筋継手の 標準的な配置は，図-2 ならびに図-4 に示す向きで考え ているが，載荷時には継手のかぶりが最小となる上下面 でのひび割れ発生が想定されることから，試験体を 90
表-3 鋼材の材料特性

\begin{tabular}{|c|c|c|c|c|c|c|}
\hline & \multirow{2}{*}{\multicolumn{2}{|c|}{ 材料種類 }} & \multirow{2}{*}{ 仕様 } & \multicolumn{3}{|c|}{ 力学特性 $\left(\mathrm{N} / \mathrm{mm}^{2}\right)$} \\
\hline & & & & ヤング係数 & 降伏強度 & 引張強度 \\
\hline \multirow{2}{*}{$\begin{array}{c}\text { シリーズ } \\
1\end{array}$} & 先端冶具 & P型, $C_{1}$ 型, T型 & SM490 & $1.91 \times 10^{5}$ & 354 & 540 \\
\hline & 鉄筋 & D19 & SD345 & $1.80 \times 10^{5}$ & 387 & 556 \\
\hline \multirow{3}{*}{$\begin{array}{c}\text { シリーズ } \\
2\end{array}$} & \multirow{2}{*}{ 先端冶具 } & T型 & SM490 & $2.07 \times 10^{5}$ & 352 & 528 \\
\hline & & $\mathrm{C}_{2}$ 型 & SM570 & $2.12 \times 10^{5}$ & 493 & 586 \\
\hline & 鉄筋 & D19 & SD345 & $1.77 \times 10^{5}$ & 383 & 555 \\
\hline
\end{tabular}

度回転させた状態で引張試験を実施し，その両面でひび 割れ状況を確認した。

先端治具と鉄筋の結合方法は，摩擦圧接とした.

試験体の製作は，先端治具を鉄筋に結合後，PCa部材 を模擬したコンクリート部分の型枠から先端治具を突出 させた状態で所定の位置に固定し，コンクリートを打込 み・養生した，その後, 先端治具を嵌合させて配置し, 外周の型枠を組み立て, 間詰め材の無収縮モルタルを打 込み・養生した。

\section{(3) 使用材料}

鉄笳は D19（SD345）の 1 種類とした.また，先端治 具の材質は，SM490，SM570を使用した。 PCa部材を模 擬したコンクリートの目標強度は道路橋 PC 床版を想定 して $50 \mathrm{~N} / \mathrm{mm}^{2}$ とした。接合部の間詰め材は，無収縮モ ルタルを適用し目標強度を $80 \mathrm{~N} / \mathrm{mm}^{2}$ とした。試験時の 材料試験の結果を表-3, 表-4 に示す. また, 間詰め材に 混入した補強繊維の仕様を表-5に示す. 
表-4 セメント系材料の材料特性

\begin{tabular}{|c|c|c|c|c|c|}
\hline & \multirow{2}{*}{ 材料種類 } & \multirow{2}{*}{ 仕様 } & \multicolumn{3}{|c|}{ 力学特性 $\left(\mathrm{N} / \mathrm{mm}^{2}\right)$} \\
\hline & & & ヤング倸数 & 圧縮強度 & 曲げ勒性係数 \\
\hline \multirow{3}{*}{ 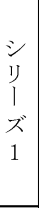 } & $\begin{array}{l}\text { コンクリート } \\
\text { (模擬床版) }\end{array}$ & C40-早強- $20 \mathrm{~mm}-12 \mathrm{~cm}$ & - & 48.7 & - \\
\hline & \multirow{2}{*}{$\begin{array}{l}\text { 無收縮モルタル } \\
\text { (間詰め部) }\end{array}$} & 繊維なし & $3.30 \times 10^{4}$ & 113 & - \\
\hline & & 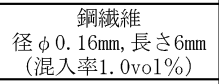 & $3.35 \times 10^{4}$ & 109 & $3.89,4.26$ \\
\hline \multirow{5}{*}{ 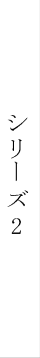 } & $\begin{array}{l}\text { コンクリート } \\
\text { (模擬床版) }\end{array}$ & C40-早強- $20 \mathrm{~mm}-12 \mathrm{~cm}$ & - & 52.1 & - \\
\hline & \multirow{4}{*}{$\begin{array}{l}\text { 览叫縮モルタルル } \\
\text { (間詰め部) }\end{array}$} & 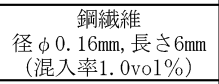 & $3.23 \times 10^{4}$ & 117 & 4.44 \\
\hline & & 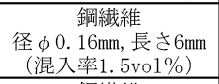 & $3.15 \times 10^{4}$ & 114 & 5.51 \\
\hline & & 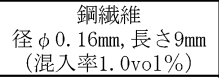 & $3.21 \times 10^{4}$ & 107 & 6.29 \\
\hline & & 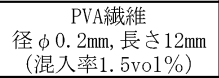 & $2.96 \times 10^{4}$ & 103 & 3.46 \\
\hline
\end{tabular}

表-5 補強繊維の仕様

\begin{tabular}{|c|c|c|c|c|c|}
\hline & \multirow{2}{*}{$\begin{array}{c}\text { 繊維径 } \\
(\mathrm{mm}) \\
\end{array}$} & \multirow{2}{*}{$\begin{array}{c}\text { 繊維長 } \\
(\mathrm{mm})\end{array}$} & \multirow{2}{*}{ 密度 } & \multicolumn{2}{|c|}{ 力学特性 $\left(\mathrm{N} / \mathrm{mm}^{2}\right)$} \\
\hline & & & & ヤング係数 & 引張強度 \\
\hline \multirow{2}{*}{ 鋼繊維 } & 0.16 & $\overline{6} 6$ & 7.85 & 200 & 2,800 \\
\hline & 0.16 & 9 & 7.85 & 200 & 2,800 \\
\hline PVA繊維 & 0.2 & 12 & 1.3 & 27 & 975 \\
\hline
\end{tabular}

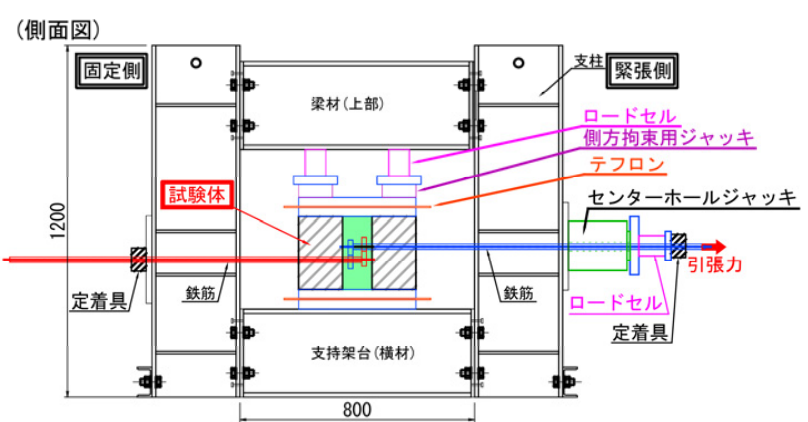

図-9 載荷装置の概要

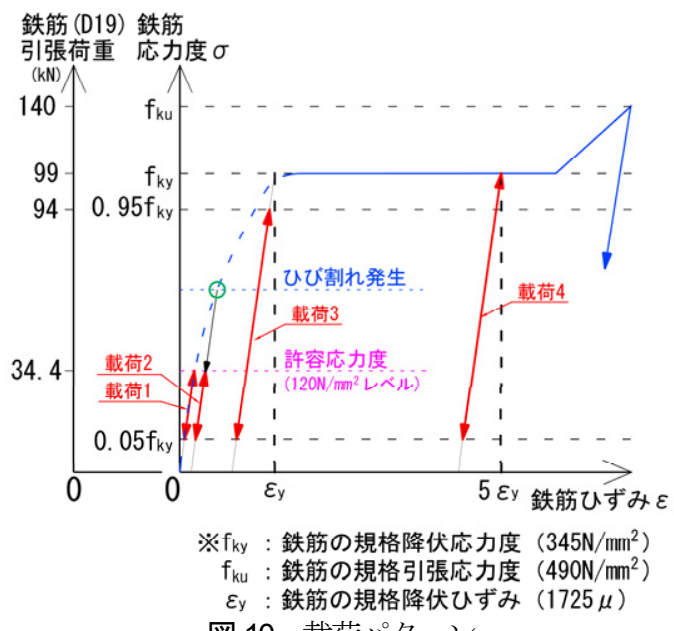

図-10 載荷パターン

\section{（4）載荷方法}

\section{a) 載荷装置}

載荷装置の概要を図-9 に示す。載荷装置は，試験体 を囲む口型の鋼製フレーム，載荷器具として緊張側に載 荷能力 $500 \mathrm{kN}$ のセンターホールジャッキ, 固定側に鉄筋
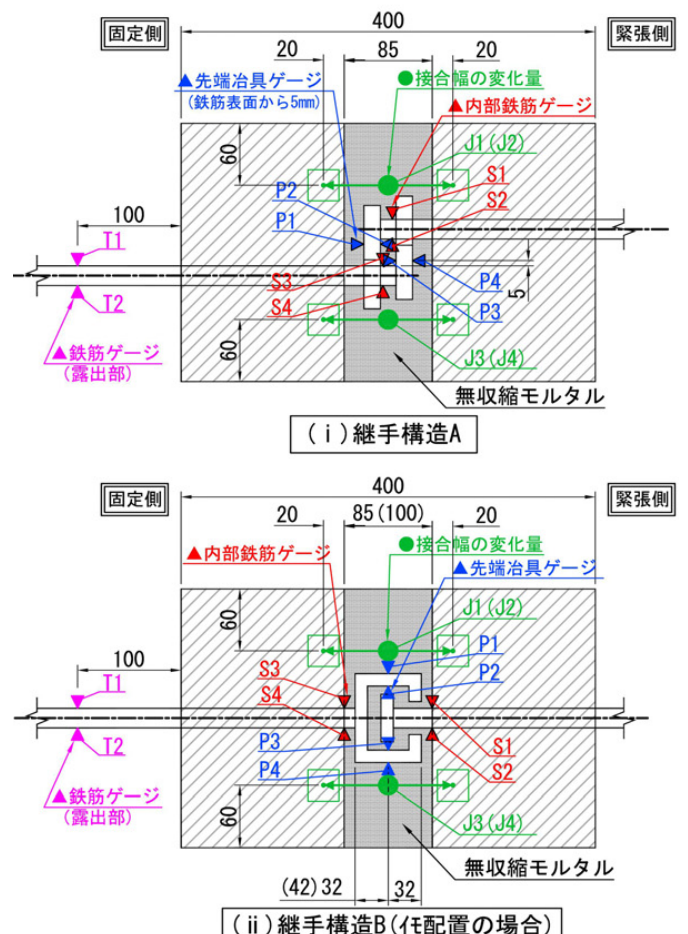

(ii ) 継手構造B (任配置の場合)

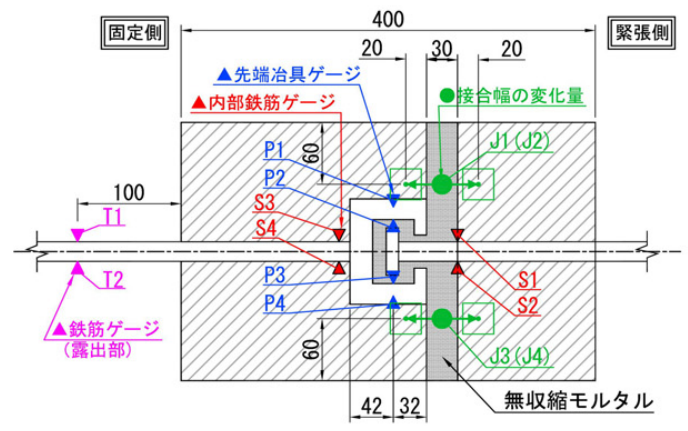

(iii) 継手構造B (千鳥配置の場合)

※貫通鉄筋の場合は，先端冶具以外は接合案 Bと同様とした.

図-11 計測機器の配置図

固定用の定着具により構成した．なお，側方拘束がある ケースでは，試験体セット時のなじみをとるために側方 拘束ジャッキ 2 個を設置し，試験開始前に各々 $1 \mathrm{kN}$ を載 荷して固定した。 また，側方拘束面にはテフロンシート を設置し試験体の移動を拘束しないよう留意した。

\section{b) 載荷パターン}

継手指針 8)を参考に，鉄筋の許容応力度レベル，高応 カレベル $\left(0.95 \mathrm{f}_{\mathrm{y}}\right)$ および高ひずタレベル $\left(5 \varepsilon_{\mathrm{y}}\right)$ の 3 段 階で，引張側（一方向）の繰返し載荷とした．また，各 レベルでの繰返し回数は各 4 回とした. なお，鉄筋の許 容応力度には，道路橋床版を想定し，道路橋示方書 $\left.{ }^{2}\right)$ 上 り $\mathrm{RC}$ 床版の鉄筋の許容応力度の推奨値 $\left(120 \mathrm{~N} / \mathrm{mm}^{2}\right)$ を採 用した。 また，許容応力度レベルの載荷は，接合部にひ び割れがない状態（載荷 1）とひび割れ発生後（載荷 2）の 2 段階で実施した。載荷パターンを図-10に示す. 
表-6＼cjkstart試験結果一覧（継手構造 A）

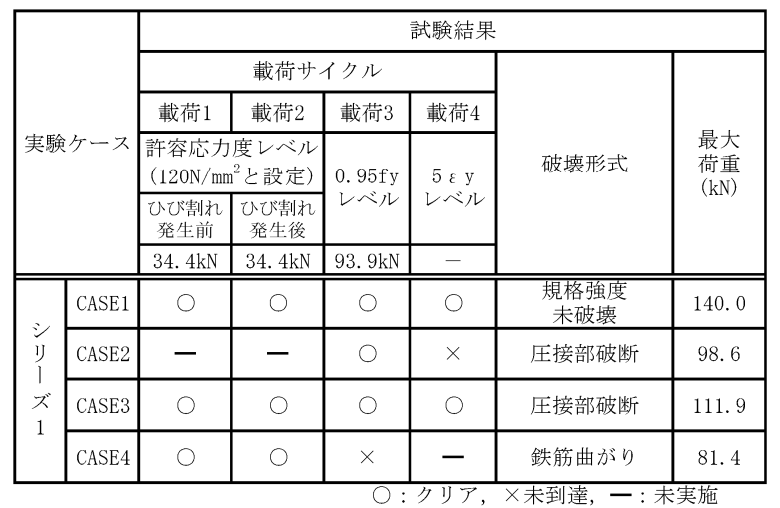

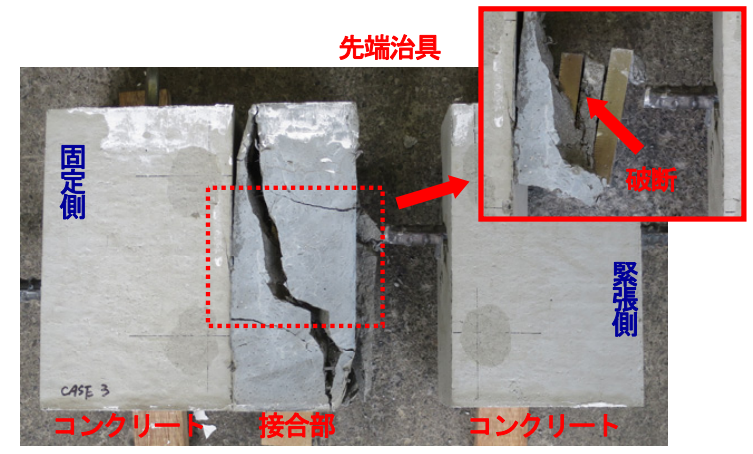

写真-1 破壊状況（継手構造 A CASE3）

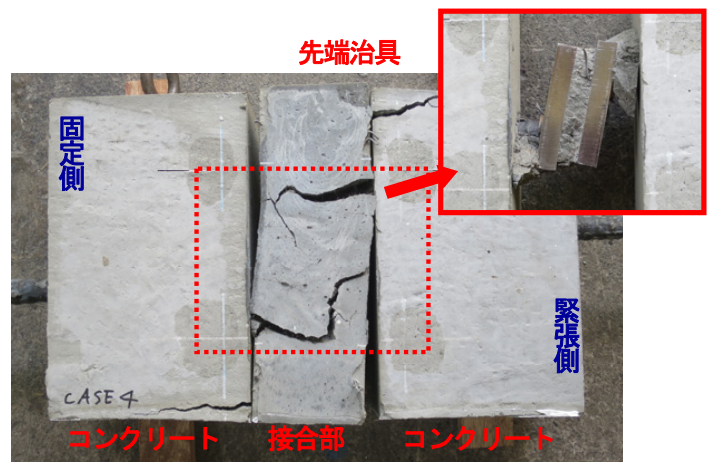

写真-2 破壊状況（継手構造 A CASE4）

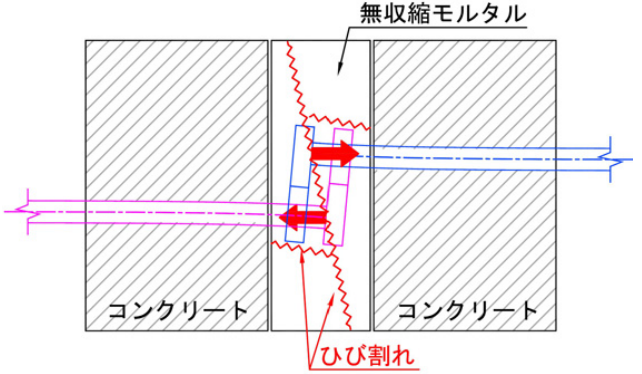

図-12 ひび割れの発生イメージ図(継手構造 A)

\section{(5) 計測}

計測は，荷重，側方拘束力，鉄筋のひずみ，先端治具 の表面ひずみ，接合部の幅（以下，接合幅）の変位量と した. 計測機器の配置図を図-11に示す.

\section{(6) 継手構造 $\mathrm{A}$ の引張試験結果}

\section{a) 破壊状況}

各ケースでの破壊に至った時期，最大荷重およひ破壊 形式を表-6 に示し，試験終了時の試験体の破壊状況の

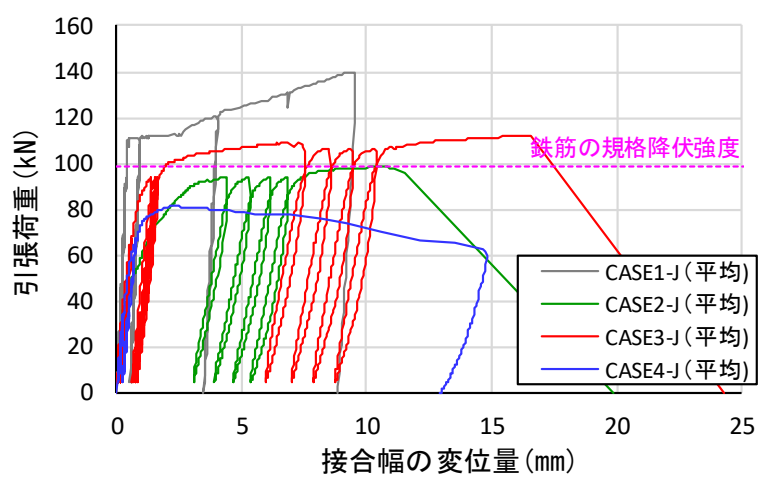

図-13 引張荷重-接合幅の変位量 (継手構造 A)

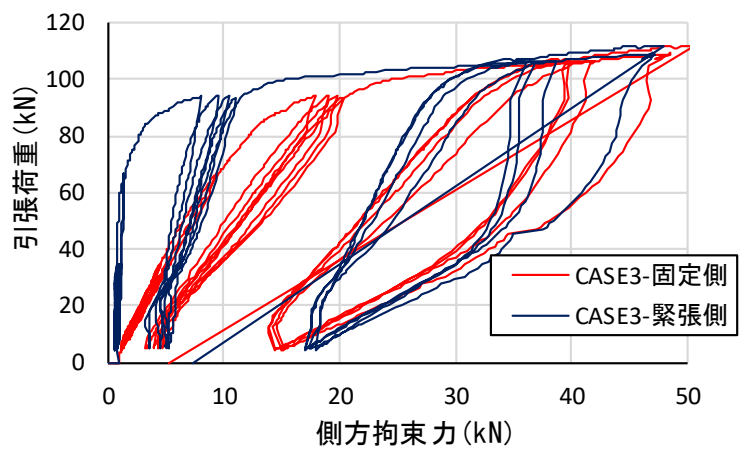

図-14 引張荷重-側方拘束力 (継手構造 A)

例として CASE3，CASE4 を写真-1，写真-2 に示す．側 方拘束のある CASE2，3 では同様の傾向を示し，図-12 に示すように，両方の $\mathrm{P}$ 型冶具の圧接部を結ぶように斜 めのひび割れが発生, 進展し, 最終的に片側の $\mathrm{P}$ 型冶具 と鉄筋の圧接部近傍の鉄筋が破断した。一方，側方拘束 のない CASE4 では，前述の斜めのひび割れは小さく, 一対の $\mathrm{P}$ 型治具の上下部付近での水平方向のひび割れや 目地部の目開きが大きく進展した。

\section{b) 継手耐力}

継手構造 A と, 貫通鉄筋におけるケースの引張荷重接合幅の変位量の関係を図-13 に示寸．なお，接合幅の 変位は, 計測箇所 4 か所の平均值とした. 最大荷重は, CASE3 $>$ CASE2 $>$ CASE4 の順で小さくなっており，側方 拘束や間詰め材の補強䋊維が継手耐力に一定の効果を有 することがわかる．また，CASE2〜CASE4 の最大荷重 は，貫通鉄筋の CASE1 に比べて下回っており，全強継 手にはならない.

\section{c）接合部全体（試験体）の挙動}

側方拘束がある場合の引張荷重-側方拘束力の関係と して CASE3 を図-14 に示寸。載荷初期から緊張側と固定 側での側方拘束力に差が生じている。.また，引張荷重露出部の鉄筋ひずみの関係を図-15 に示寸．側方拘束の ある場合(CASE3)では鉄筋に曲げが作用していないが, 側方拘束のない場合（CASE4）は，載荷初期から鉄筋両 面のひずみ差が急激に増加しており鉄筋に曲げが作用し ている．前述の間詰め部のひび割れ，目地部の目開き幅， 側方拘束力および露出部の鉄筋ひずみ等から総合的に判 


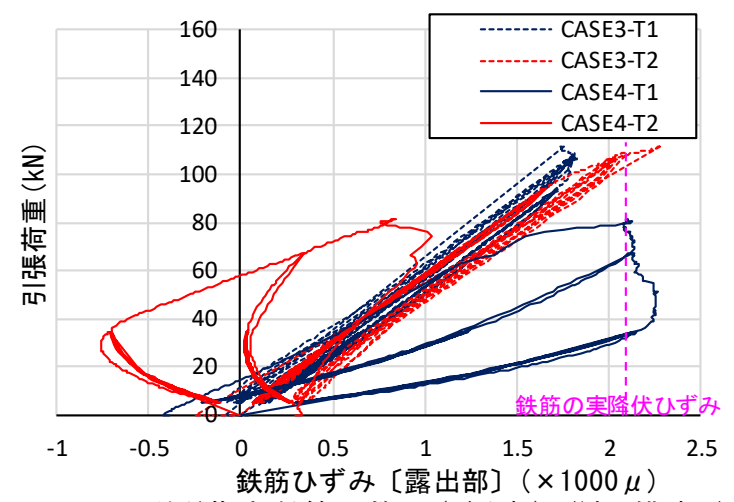

図-15引張荷重-鉄筋ひずみ（露出部）（継手構造 A）

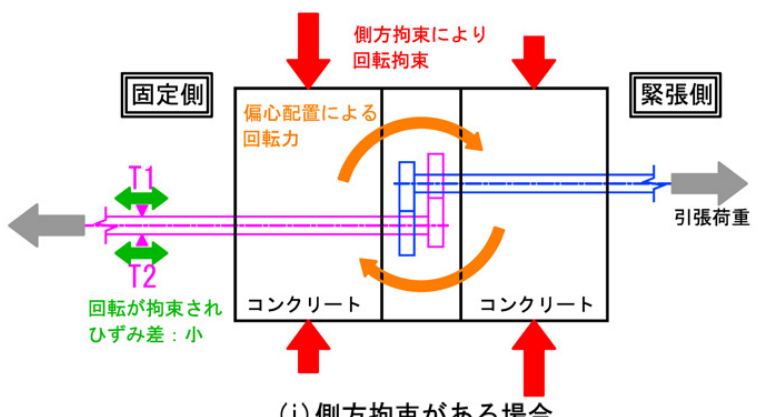

(i) 側方拘束がある場合

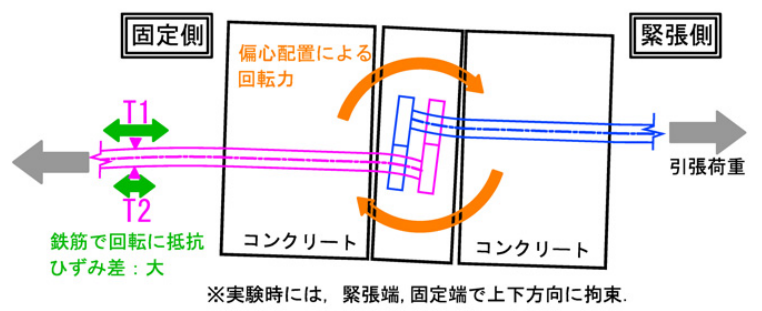

(ii ) 側方拘束がない場合

図-16 継手鉄筋の偏心による回転

断すると，継手構造 A では対向する鉄筋が偏心配置の ため, 載荷に伴って生じる図-16 のような回転力の影響 が大きいことがわかる.

\section{d) 継手近傍の挙動}

引張荷重-内部鉄笳ひずみの関係を図-17 に, 先端治具 のひずみを図-18 に示す，内部鉄筋のひずみは，すべて のケースにおいて, 荷重 50〜 63kN 程度で継手内側 （S2）が降伏に至っている．また，先端治具のひずみは, CASE2 および CASE4 は最後まで降伏が確認されず, CASE3 の場合でも0.95fy 繰返し載荷時点（荷重 $93.9 \mathrm{kN}$ ) では降伏に至らず，荷重 $108 \mathrm{kN}$ 程度で降伏に至っている. このように, 継手構造 $\mathrm{A}$ の現仕様では, $\mathrm{P}$ 型治具より も結合している鉄筋の方が先行して降伏している.した がって，継手構造 A では，寸法上の制約（対向する鉄 筋の偏心量 $45 \mathrm{~mm}$ )を維持した場合, P 型治具の仕様を高 めても継手耐力の向上が見込めないと判断できる.

\section{(7) 継手構造 B の引張試験結果}

\section{a) 破壊状況}

各ケースでの破壊に至った時期，最大荷重およひ破壊 形式を表-7に，試験終了時の試験体の破壊状況の例と

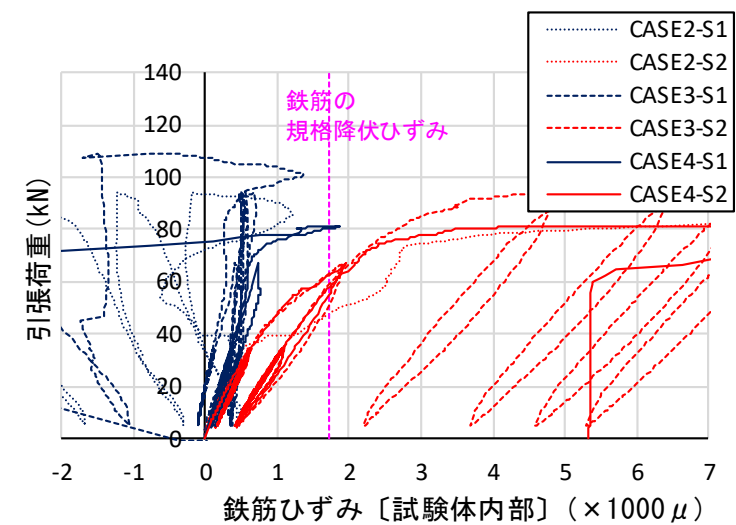

図-17引張荷重一内部鉄筋ひずみ（継手構造 A）

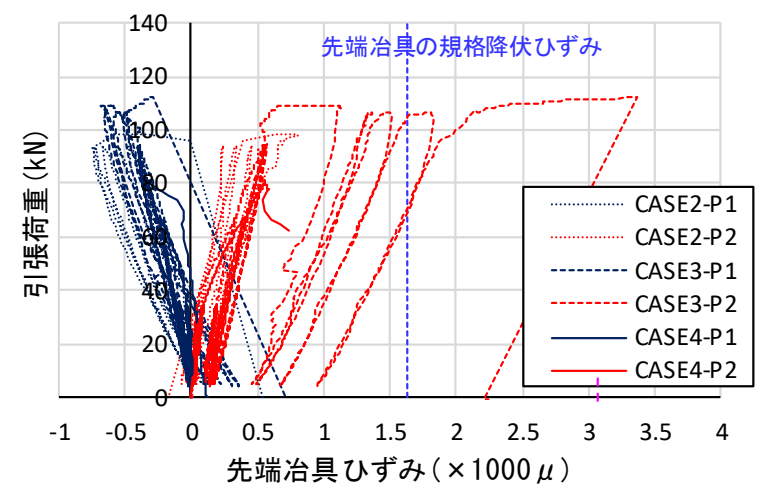

図-18 引張荷重-先端治具ひずみ（継手構造 A)

表-7＼cjkstart試験結果一覧（継手構造 B)

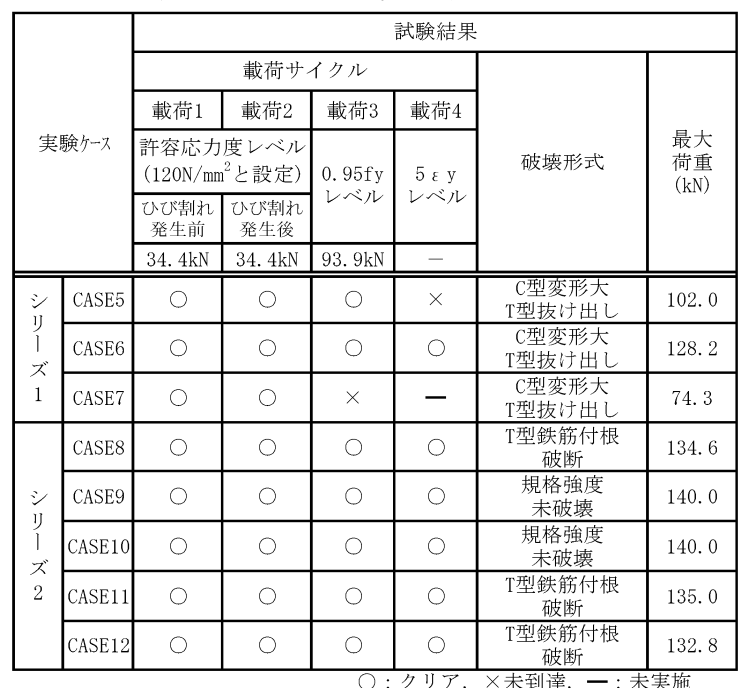

して CASE6( $\mathrm{C}_{1}$ 型) と CASE10(C $\mathrm{C}_{2}$ 型)を写真-3, 写真-4に示 す.いずれの場合も載荷とともに C 型治具の開口側が 開こうとするため水平方向のひび割れが先行して入り, その後, 鉛直方向のひび割れが発生，進展していく．終 局時には, シリーズ 1 では, すべてのケースで $\mathrm{C}_{1}$ 型治 具が大変形し $\mathrm{T}$ 型治具が抜け出して破壊した. これら の現象は，構造成立性を確認するために使用した先端冶 具のうち, $\mathrm{C}_{1}$ 型冶具 (SM490, 板厚を一律 $12 \mathrm{~mm}$ ) の剛 性が小さいことに起因すると考えられたため, それを見 直し $\mathrm{C}_{2}$ 型冶具を使用してシリーズ 2 を実施した. 見直 しに当たり, 図-19 に示寸ように C 型治具のみを考慮し 


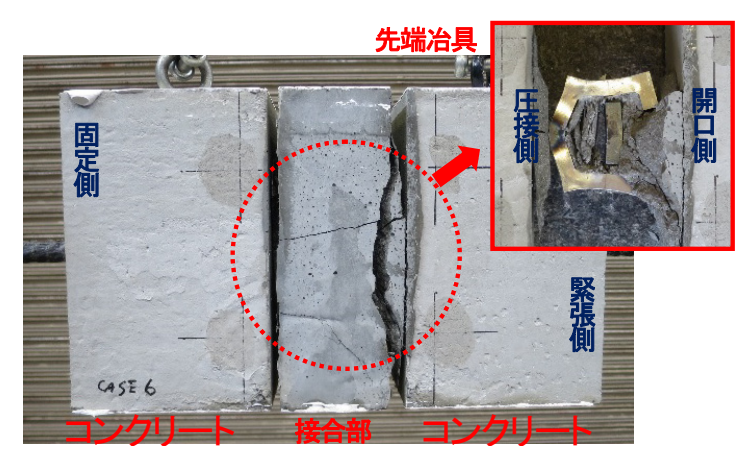

写真-3 破壊状況（継手構造 B CASE6）

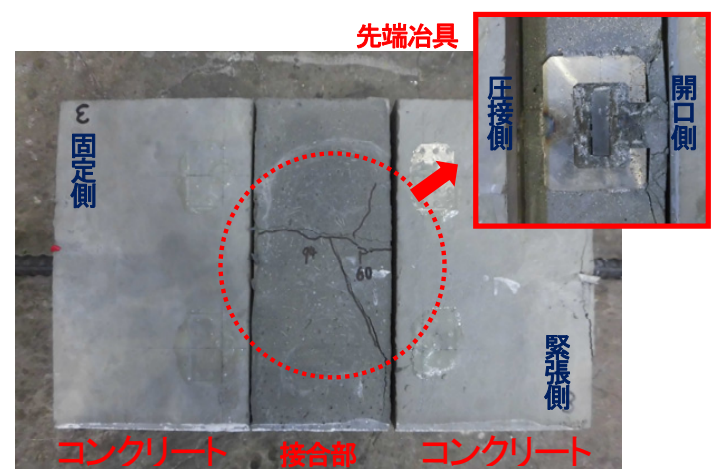

写真-4 破壊状況（継手構造 B CASE10）

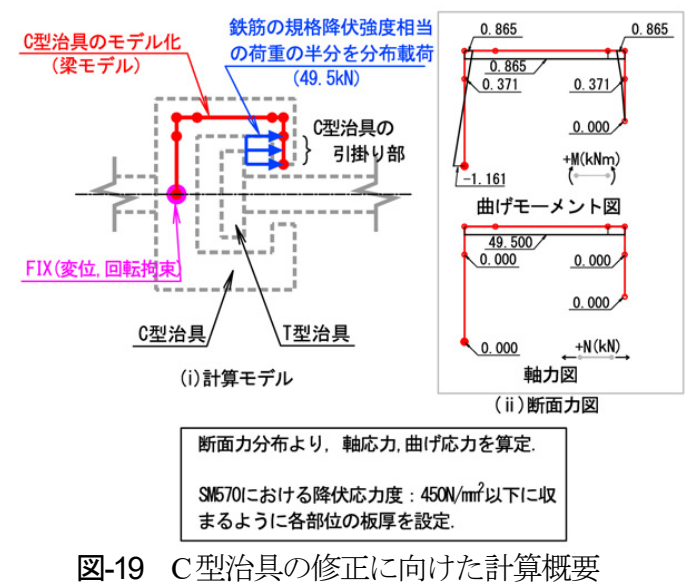

た梁モデルの弾性計算を行い， $\mathrm{C}$ 型治具の引掛かり部 に鉄筋の規格降伏強度レベルの引張荷重が直接作用して も，C型治具が先行して降伏しないように材質を SM570 にランクアップし，また，図-8 のように部位ごとに板 厚を設定した。 その結果, シリーズ 2 では, 最後まで C 型治具の変形はかなり小さく, $\mathrm{T}$ 型治具の抜け出しはな かった。

\section{b) 継手耐力}

継手構造 B と, 貫通鉄筋におけるケースの引張荷重接合幅の変位量の関係を図-20 に示す．なお，接合幅の 変位量は計測箇所 4 か所の平均值とした. シリーズ 1 で は，最大荷重は，CASE6 >CASE5 >CASE7 の順で小さく なっており，継手構造 A の場合と同様に，側方拘束や 間詰め材への繊維の混入が継手耐力に一定の効果を有す ることを確認できた．次に，シリーズ 1 の CASE6（C1

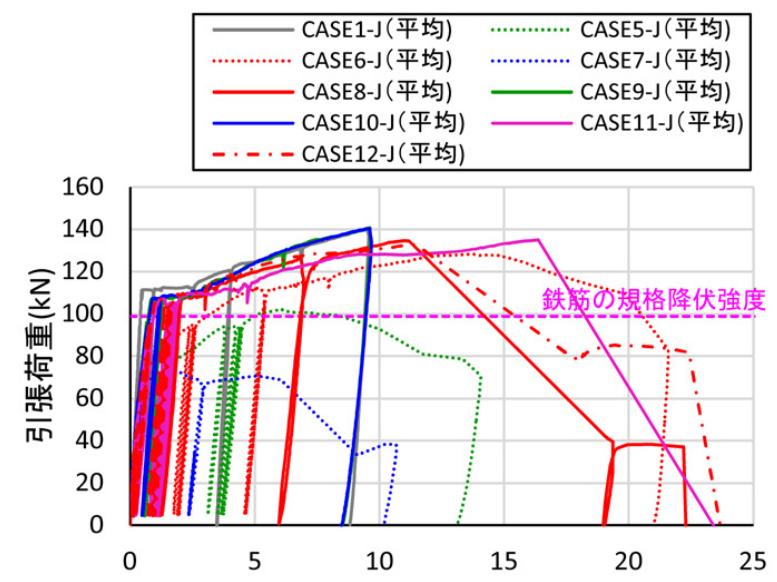

接合幅の変位量 $(\mathrm{mm})$

図-20 引張荷重-接合幅の変位量(継手構造 B)
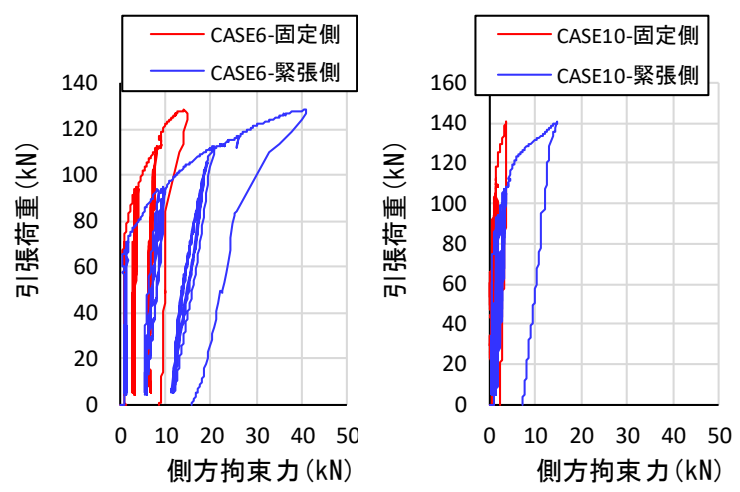

図-21 引張荷重-側方拘束力(継手構造 B)

型）とシリーズ 2 の CASE8（C2 型）を比較すると, CASE8 の方が最大荷重は増加した。これは，CASE6 の 破壊モードが $\mathrm{C}_{1}$ 型治具の大変形による $\mathrm{T}$ 型治具の抜け 出しだったことに対して, CASE8 では $\mathrm{C}_{2}$ 型治具の岡性 を高め変形を小さく抑制できたために $\mathrm{T}$ 型治具側の鉄 筋部分の破断となったことからも，C 型治具の仕様変更 の効果と考えられる。 また，シリーズ 2 において，継手 冶具がイモ配置（CASE8～CASE11）の場合，間詰め材 の材料試験で曲げ勒性係数が高く, 䋊維補強の効果が高 いと想定される上位 2 ケース（CASE9，CASE10）で継 手耐力が鉄筋の規格引張強度以上（CASE1 と同等）で あることを確認できたが，それ以外の 2 ケース（CASE8， CASE11）は，荷重 $135 \mathrm{kN}$ 程度で $\mathrm{T}$ 型治具と鉄筋の圧接 部近傍で鉄筋が破断した。これは，CASE8 やCASE11の ように間詰め部の繊維補強の効果が小さい場合，作用引 張力に対して䋊維が分担して抵抗する効果が小さくなる ため， $\mathrm{T}$ 型治具のプレートが鉄筋との接合部を中心に曲 げ変形し，鉄筋付け根の溶接部で単純な引張だけでなく 曲げ応力が加担したためと推察される. また, 継手治具 の配置の影響は，CASE8 (イモ配置) と CASE12（千鳥 配置) を比較しても有意な差は確認されなかった.

\section{c) 接合部全体（試験体）の挙動}

側方拘束がある場合の引張荷重-側方拘束力の関係と 


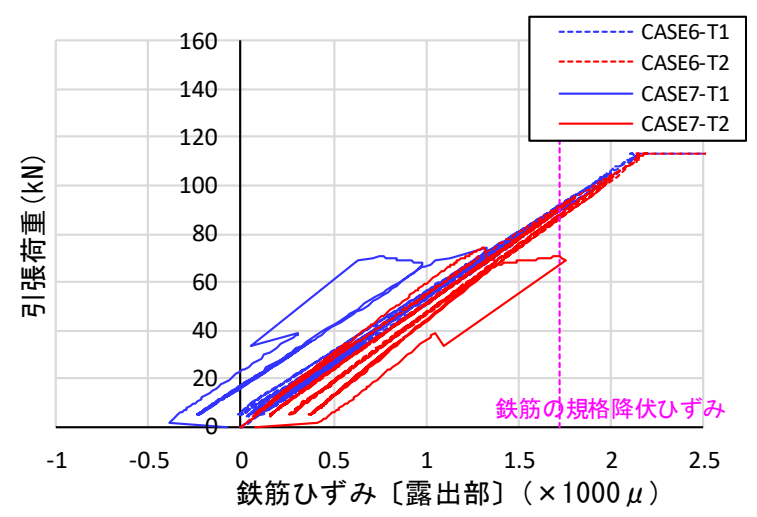

図-22 引張荷重一鉄筋ひずみ（露出部）（継手構造 B)

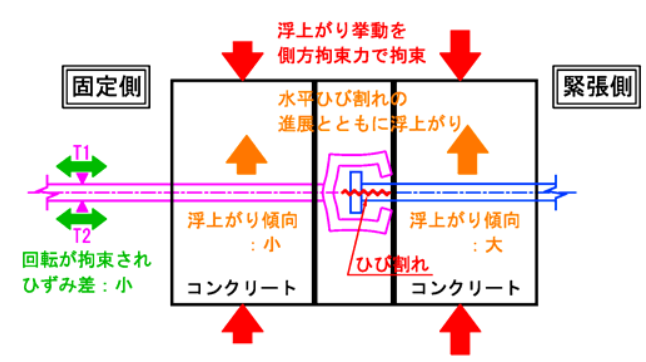

(i) 側方拘束がある場合

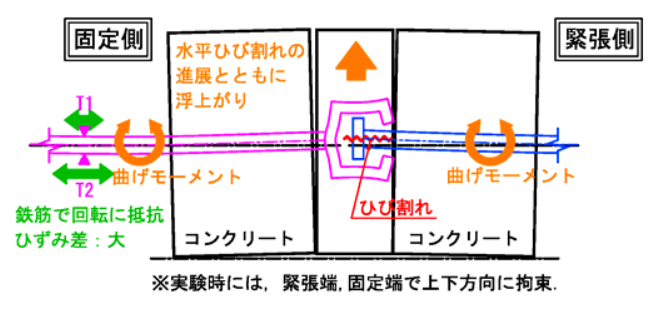

(ii ) 側方拘束がない場合

図-23 水平ひび割れの進展に伴う浮上がり

して， $\mathrm{C}_{1}$ 型治具を用いた CASE6， $\mathrm{C}_{2}$ 型治具を用いた CASE10 を図-21 に示す. 継手構造 A とは異なり，側方 拘束力は，載荷初期では固定側と緊張側の差異がなく小 さい範囲で推移しており, 荷重 $60 \mathrm{kN}$ 程度を超えた時点 から緊張側の方が大きくなっている．固定側と緊張側の 差異が生じはじめる荷重は, ケースにより多少のばらつ きはあるが，接合部のひび割れ発生荷重と同程度であっ た．なお，継手構造 B のすべてのケースで同様の傾向 であった．また，引張荷重-露出部の鉄筋ひずみの関係 を図-22 に示寸，本図は側方拘束の有無による違いを示 寸ため，側方拘束がある場合(CASE6)と側方拘束が無い 場合（CASE7）を示している。いずれのケースも載荷初 期は，鉄筋両側で同程度のひずみが発生している.

CASE6 は最後までこの傾向であったが，CASE7 は荷重 $60 \mathrm{kN}$ 程度で水平ひび割れを発生後, 荷重 $74 \mathrm{kN}$ 程度で一 気に差が生じた.

以上の現象は, 図-23 に示寸ように, 引張荷重の増加 とともに接合部の水平ひび割れが発生し，さらに $\mathrm{C}$ 型 治具（開口部は緊張側）が開くことにより，試験体が側 方（試験時の上方）に浮き上がろうとすることに起因す
ると考えられる.この挙動に対して，側方拘束力がある 場合は側方拘束力で抵抗し露出部の鉄筋は曲げが作用し ないのに対して，側方拘束がない場合は試験方法上，固 定端や緊張端は上下方向に動かないこともあり, 露出部 の鉄筋の曲げで浮上がりに抵抗したものと考えられる.

\section{d) 継手近傍の挙動}

引張荷重-内部鉄筋ひずみ, 引張荷重-先端治具ひずみ, の関係を, 各ケースの載荷履歴と併せて図-24 に示す. まず，先端治具に $\mathrm{C}_{1}$ 型を使用したシリーズ 1 について 記載する．内部鉄筋ひずみは，側方拘束のある場合

（CASE5 ならびに CASE6），鉄筋の規格降伏強度相当 の荷重前の $80 \mathrm{kN}$ 程度で引張側から降伏している. 一方, 計測箇所の $\mathrm{C}$ 型治具 $\left(\mathrm{C}_{1}\right.$ 型)ひずみは，その段階で線形的 な挙動であり，降伏に至っていない， $\mathrm{C}_{1}$ 型治具外側

(P1)のひずみ挙動の特徵として, 引張荷重の作用とと もに曲げにより圧縮域となるが，最大荷重の増大ととも に除荷時でも引張応力が残存する．これは，載荷ととも に $\mathrm{C}_{1}$ 型治具が変形し, 計測箇所以外の部分で先行して 塑性変形が生じているため, 除荷とともに計測箇所で引 張が発生しているか, もしくは, 継手近傍で $\mathrm{C}_{1}$ 型治具 の変形により間詰め材が局所的に破壊し，開口したひび 割れが完全に閉じない状態となり，除荷時に引張が残存 寸る等が考えられる。 また，側方拘束のない場合

(CASE7) では，ひび割れの発生直後（引張荷重 $62 \mathrm{kN}$ 程度）に $\mathrm{C}_{1}$ 型治具の変形や試験体の浮上がりが急激に 進展し $\mathrm{C}_{1}$ 型治具が降伏し，それを追うように内部鉄筋 が一気に降伏したと想定される。いずれにしても $\mathrm{C}_{1}$ 型 治具の剛性が小さいためと考えられる.

次に, シリーズ 2 にいて記載する.内部鉄筋ひずみ は，鉄筋の規格降伏強度 $(98.8 \mathrm{kN})$ 程度の載荷状態では, CASE12 以外では各ケースの諸条件によらず降伏に至っ ていない，また， $\mathrm{C}$ 型治具 $\left(\mathrm{C}_{2}\right.$ 型)ひずみは，鉄筋の規格 降伏強度の $95 \%$ の載荷 $(93.9 \mathrm{kN})$ 時点ではすべてのケース で降伏しておらず，除荷時も $\mathrm{C}_{2}$ 型治具の外側（P1）で 引張の残留応力が残存する等の状態は確認されなかった. 間詰め材の補強繊維の仕様の違いによる CASE8〜 CASE11では, PVA䋊維の場合 (CASE11) は, 他の3 一スと比較して $\mathrm{C}_{2}$ 型治具の発生ひずみが大きい，それ 以外の鋼繊維の 3 ケースでは降伏荷重レベルでは有意な 差は確認できなかったが，規格引張荷重（140kN）では $\mathrm{C}_{2}$ 型治具の外側（P1）の引張ひずみは, CASE8 >CASE9 $>$ CASE10 の順で小さくなっており，これからも補強効 果の高い繊維補強モルタルほどひび割れ発生後でも接合 部の間詰め材が引張力を分担していると考えられる. 継 手配置を千鳥とした場合（CASE12）は，イモ配置の場 合 (CASE8 : 配置以外同条件) と比較すると, 内部鉄筋 は降伏に早く至っており，C 型治具のひずみも大きい. これは，千鳥配置の場合， $\mathrm{C}$ 型治具の周囲が接合部の間 

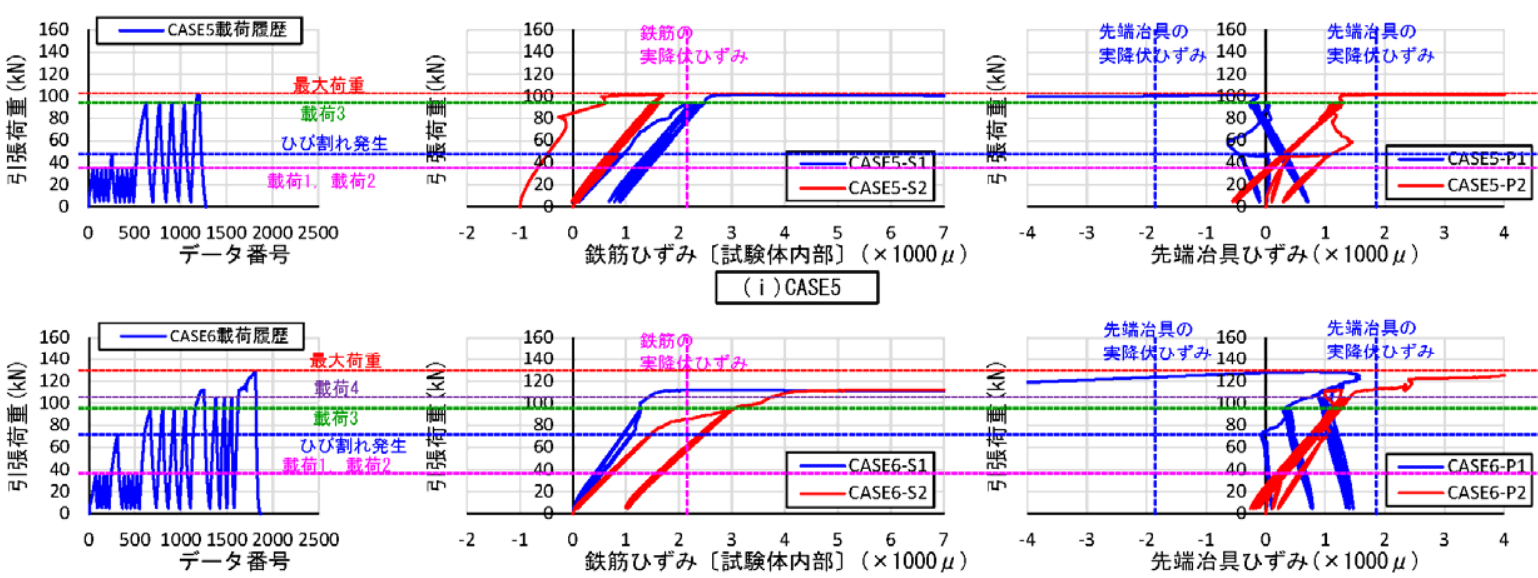

(ii) CASE6

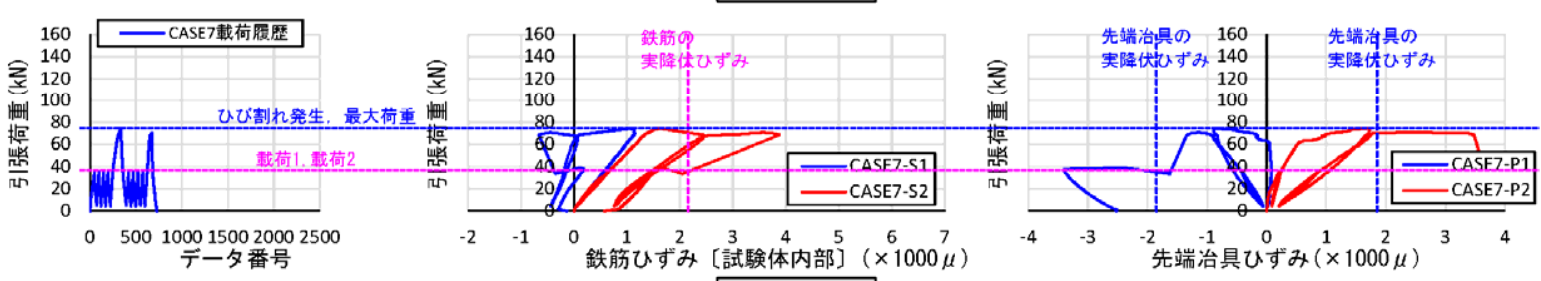
(iii) CASE7
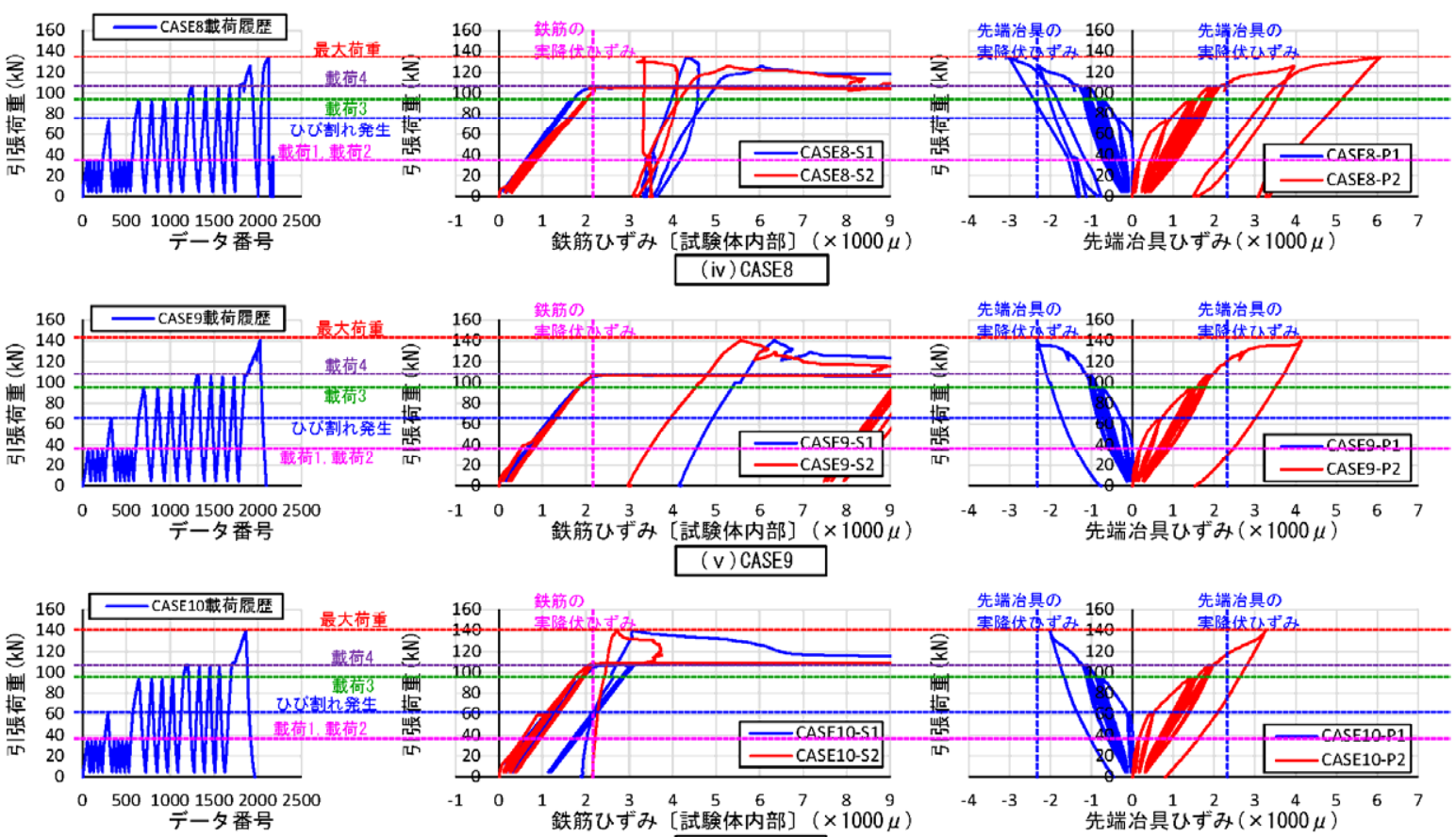
(vi) CASE10

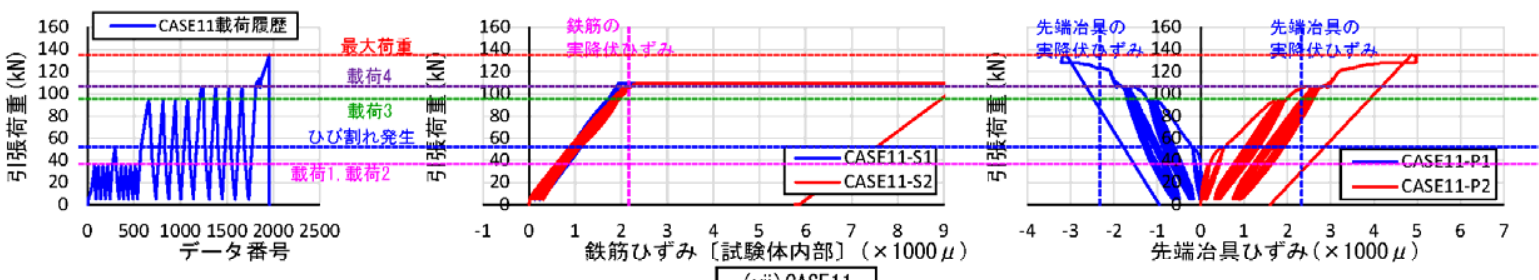
(vii) CASE11

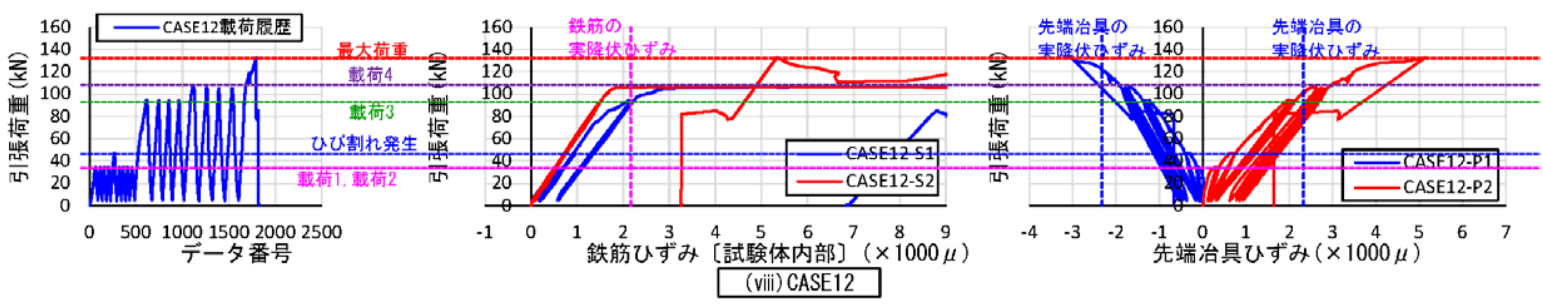

図-24引張荷重-載荷履歴，内部鉄筋ひずみ，先端治具ひずみ (継手構造 B) 
詰め材より強度の低いコンクリートであること，C 型治 具外周に間詰め材との打継目があり，その打継目では付 着力のみで抵抗し, 目開き時に補強繊維の効果が見込め ないためと考えられる.

以上から，継手構造 $\mathrm{B}$ は， $\mathrm{C}_{2}$ 型治具を採用し，間詰 め材の補強繊維を鋼繊維（繊維長 $9 \mathrm{~mm}$ 混入量 $1 \%$ もく は繊維長 $6 \mathrm{~mm}$ 混入量を $1.5 \%$ ） とすれば，鉄筋継手とし て適用できる可能性があると考えられる.

\section{4. 静的曲げ載荷試験}

次に PCa 床版を模擬した試験体を用いて静的載荷に よる性能検証を行った．静的曲げ載荷試験では，使用荷 重作用時のひび割れ状況（而久性），曲げ耐力およひ破 壊状況を確認することを目的とした.

\section{(1) 試験ケース}

試験ケースを表-8 に示す。試験対象とする継手は, 継手構造 $\mathrm{A}$ と継手構造 $\mathrm{B}\left(\mathrm{C}_{2}\right.$ 型) とした. 継手構造 $\mathrm{A}$ は, 継手単体の引張試験では鉄筋配置の偏心の影響もあ り十分な継手性能を確認できなかったが，床版の継手と しては性能を満足できる可能性もあるため, 併せて実施 した. また, 継手構造 B は, 継手単体の引張試験から イモ配置ならびに千鳥配置の場合の継手耐力が同程度で あったことを踏まえて，両配置で実施した．なお，新継 手構造と併せて，比較する基準試験体として重ね継手と ループ継手のケースも実施した.

\section{(2) 試験体の概要}

試験体の外形寸法は, 軸方向 3,030mm, 軸直角方向 $900 \mathrm{~mm}$, 高さ $250 \mathrm{~mm}$ とし, 軸方向の支間中央に各継手 を設けた，基準試験体の重ね継手は，コンクリート標準 示方書 ${ }^{3)}$ を参考に, 継手長 $570 \mathrm{~mm}(30 \varphi)$, 接合幅を $650 \mathrm{~mm}$ とし，また，ループ継手は，設計要領第二集建 設橋梁編 ${ }^{13)}$ を参考に, 内曲げ直径 $131 \mathrm{~mm}$, 継手長 $290 \mathrm{~mm}$ ，接合幅 $340 \mathrm{~mm}$ とした．なお，ループ継手は接 合部にあごを設けず，打継目を垂直な面とした．新継手 の接合部の打継目は, 深さ $30 \mathrm{~mm}$ の凹のせん断キーを設 け，打継ぎ処理を施した。

試験体の製作は，通常の施工状態を考慮し，PCa 部を 先行して打込み・養生し, その後, 接合部の間詰め材を 充填・養生した. 試験体の概要を図-25に示寸.

\section{(3) 使用材料}

コンクリートは, PCa 部材を模擬した部分と重衫継手 やループ継手の接合部の間詰め材に用いる. これらの目 標強度は, 道路橋 PC 床版を想定して $50 \mathrm{~N} / \mathrm{mm}^{2}$ とした。 表-8＼cjkstart試験ケース一覧（曲げ試験）

\begin{tabular}{|c|c|c|c|c|c|}
\hline \multirow{2}{*}{$\begin{array}{c}\text { 曲げ試験 } \\
\text { 実験ケース } \\
\end{array}$} & \multicolumn{4}{|c|}{ 継手仕様 } & \multirow{2}{*}{$\begin{array}{l}\text { 継手 } \\
\text { 配置 } \\
\end{array}$} \\
\hline & 継手形式 & 先端 & 具 & 1プ & \\
\hline CASE1 & 重齐継手 & - & - & - & - \\
\hline CASE2 & ループ継手 & - & - & - & - \\
\hline CASE3 & 継手構造A & P型 & - & P型 & イモ \\
\hline CASE4 & 継手構造B & $\mathrm{C}_{2}$ 型 & - & T型 & イモ \\
\hline CASE5 & 継手構造B & $\mathrm{C}_{2}$ 型 & - & T型 & 千鳥 \\
\hline
\end{tabular}
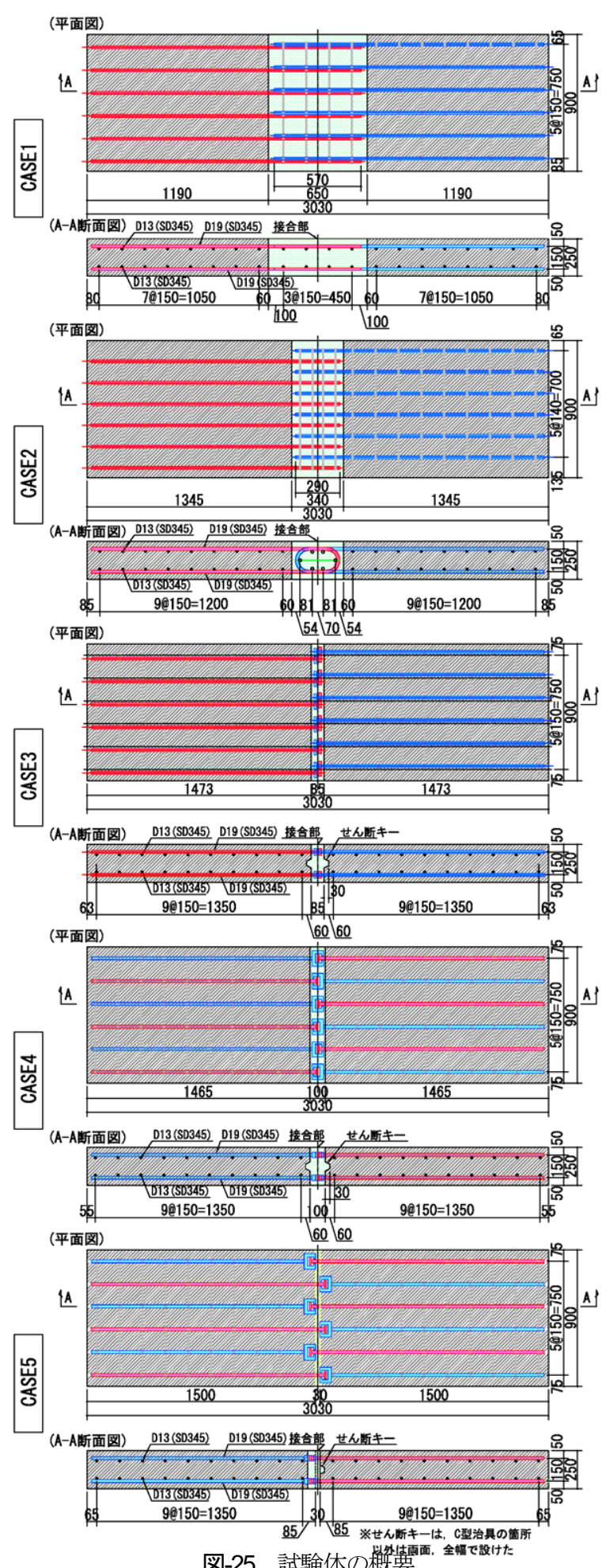

図-25試験体の概雬

また，新継手構造の間詰め材に使用する無収縮モルタル の目標強度は $80 \mathrm{~N} / \mathrm{mm}^{2}$ とした。 
表-9 鋼材の材料特性

\begin{tabular}{|c|c|c|c|c|c|}
\hline \multicolumn{2}{|c|}{ 材料種類 } & \multirow{2}{*}{ 仕様 } & \multicolumn{2}{|c|}{ 力学特性 $\left(\mathrm{N} / \mathrm{mm}^{2}\right)$} \\
\cline { 4 - 6 } & & ヤング係数 & 降伏強度 & 引張強度 \\
\hline \hline \multirow{2}{*}{ 先端冶具 } & P型, T型 & SM490 & $2.07 \times 10^{5}$ & 352 & 528 \\
\cline { 4 - 6 } & $C_{2}$ 型 & SM570 & $2.12 \times 10^{5}$ & 493 & 586 \\
\hline 鉄筋 & D19 & SD345 & $1.77 \times 10^{5}$ & 383 & 555 \\
\hline
\end{tabular}

表-10 セメント系材料の材料特性

\begin{tabular}{|c|c|c|c|c|}
\hline \multirow{2}{*}{ 材料種類 } & \multirow{2}{*}{ 仕様 } & \multicolumn{3}{|c|}{ 力学特性 $\left(\mathrm{N} / \mathrm{mm}^{2}\right)$} \\
\hline & & ヤング係数 & 王縮強度 & 曲げ勒性係数 \\
\hline $\begin{array}{l}\text { コンクリート } \\
\text { (模擬床版) }\end{array}$ & C50-早強- $20 \mathrm{~mm}-12 \mathrm{~cm}$ & $3.91 \times 10^{4}$ & 71.1 & - \\
\hline $\begin{array}{l}\text { コンクリート } \\
\text { (間詰め部) }\end{array}$ & C45-早強- $20 \mathrm{~mm}-12 \mathrm{~cm}$ & $3.45 \times 10^{4}$ & 50.1 & - \\
\hline $\begin{array}{l}\text { 無收縮モルタル } \\
\text { (間詰め部) }\end{array}$ & $\begin{array}{c}\text { 鋼緎維 } \\
\text { 径 } \phi 0.16 \mathrm{~mm}, \mathrm{~m} \\
(\text { 混入率1.0vol\%) }\end{array}$ & $3.33 \times 10^{4}$ & 111.5 & 7.97 \\
\hline
\end{tabular}

表-11 補強繊維の仕様

\begin{tabular}{|c|c|c|c|c|c|}
\hline & 纎維径 & 繊維長 & \multirow{2}{*}{ 密度 } & \multicolumn{2}{|c|}{ 力学特性 $\left(\mathrm{N} / \mathrm{mm}^{2}\right)$} \\
\cline { 5 - 6 } & $(\mathrm{mm})$ & $(\mathrm{m})$ & & ヤング係数 & 引張強度 \\
\hline \hline 鋼繊維 & 0.16 & 9 & 7.85 & 200 & 2,800 \\
\hline
\end{tabular}
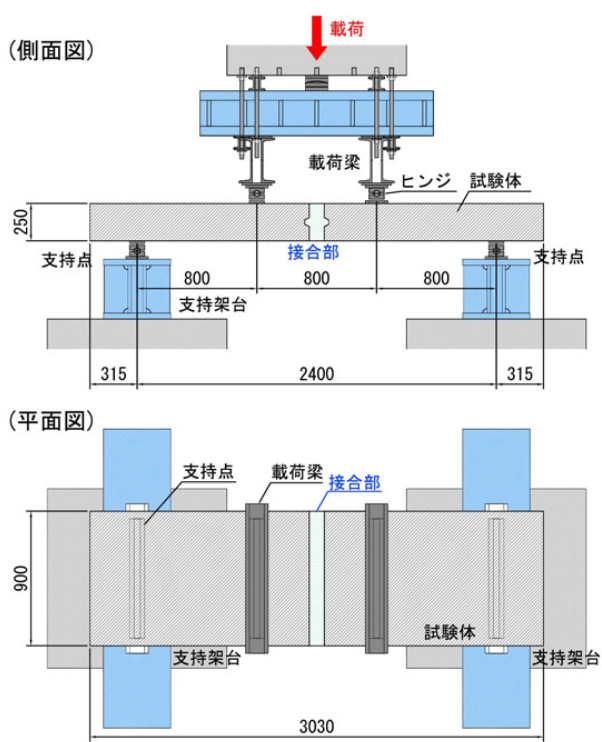

図-26 載荷装置

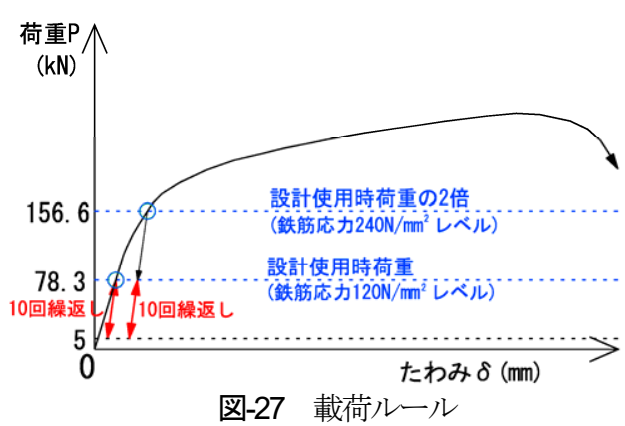

先端治具は，継手単体の引張試験で使用したものと同 仕様（P 型， $\mathrm{T}$ 型， $\mathrm{C}_{2}$ 型）とした。試験時の材料試験の 結果を表-9，表-10 に示す。また，間詰め材の補強䋊維 は, 継手単体の引張試験の結果から, 鋼繊維, 繊維径 $0.16 \mathrm{~mm}$ ，繊維長 $9 \mathrm{~mm}$ 混入率 $1.0 \mathrm{vol} \%$ の一種類とした．補 強繊維の仕様を表-11 に示す.

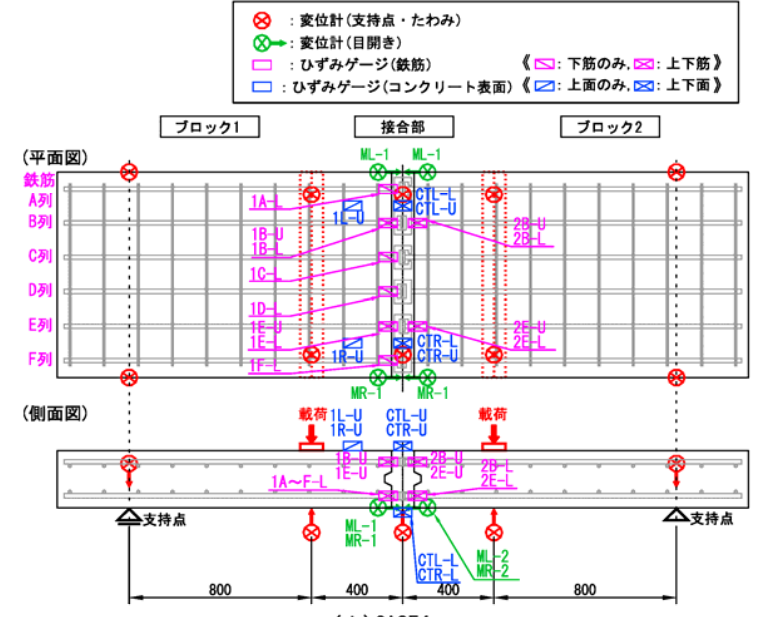

( i ) CASE4

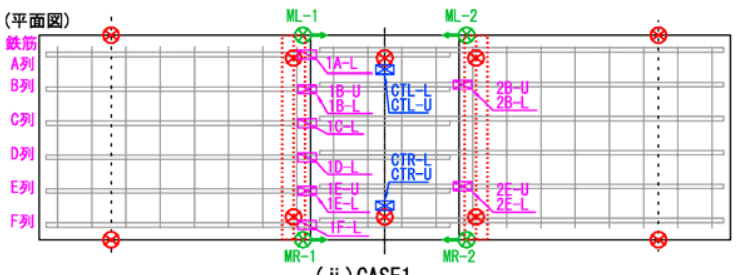

(ii ) CASE1

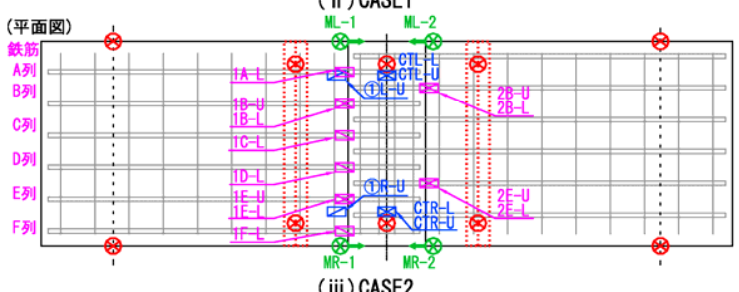

図-28 計測機器の配置

\section{(4) 実験方法}

\section{a) 載荷装置}

試験は載荷能力 $10 \mathrm{MN}$ 試験機を用いて載荷した。試験 装置の概要を図-26 に示す。支持点間隔を $2,400 \mathrm{~mm}$ ，載 荷点間距離（等曲げモーメント区間）を $800 \mathrm{~mm}$ とした。 載荷点ならびに支持点の 4 箇所のうち, 載荷点の片側を ピンとし，それ以外の 3 箇所はピンローラーとした。

\section{b) 載荷方法}

使用時の繰返し荷重の影響を確認するため，使用時荷 重レベルを繰返し載荷した．なお，繰返し回数は，既往

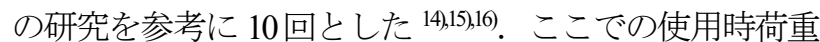
レベルは，道路橋床版を想定し，下筋での鉄筋発生応力 を $120 \mathrm{~N} / \mathrm{mm}^{2}$ 相当とした。 また，接合部のひび割れ発生 後の繰返し載荷の挙動も確認するため, 一度, 実試験体 におけるひび割れ発生モーメント相当の $100 \mathrm{kN}$ の全載荷 荷重に対して，使用時荷重の 2 倍の荷重 $(156.6 \mathrm{kN})$ を載荷 させて確実にひび割れを発生させた後に，再度使用時荷 重で 10 回の繰返し載荷を行った。載荷ルールを図-27に 示す.

\section{(5) 計測項目}

計測は，載荷荷重のほか，試験体のたわみ，打継目の 
表-12 破壊状況一覧

\begin{tabular}{|c|c|c|}
\hline $\begin{array}{c}\text { 曲げ試験 } \\
\text { 実験ケース }\end{array}$ & 破壊形式 & $\begin{array}{c}\text { 全載荷荷重 } \\
\operatorname{Max}(\mathrm{kN})\end{array}$ \\
\hline \hline CASE1 & 曲げ破壊 & 392 \\
\hline CASE2 & 曲げ破壊 & 368 \\
\hline CASE3 & 鉄筋破断を伴ら曲げ破壊 & 303 \\
\hline CASE4 & 曲げ破壊 & 387 \\
\hline CASE5 & 曲げ破壊 & 398 \\
\hline
\end{tabular}

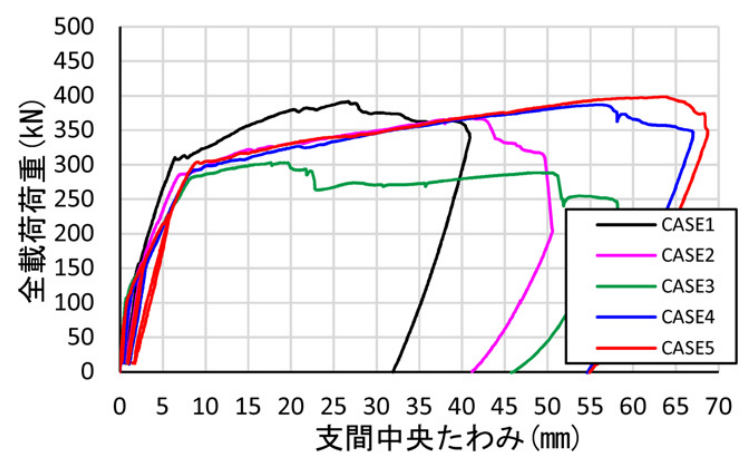

図-29 全載荷荷重-支間中央たわみ

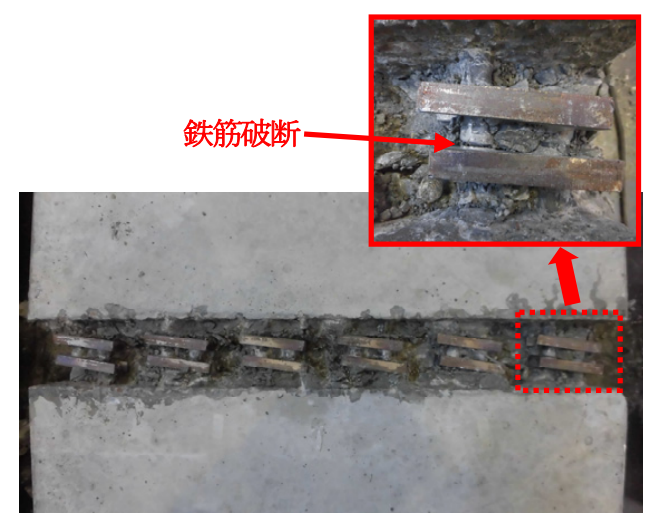

写真-5 試験後の継手部（継手構造 A : 下筋）

目開き量，鉄筋ならびにコンクリート表面のひずみとし た. 計測箇所を図-28に示す.

\section{（6）静的曲げ載荷試験の結果}

\section{a) 破壊形式ならびに荷重一たわみ}

破壊形式ならびに全載荷荷重（最大）を表-12 に示す. すべてのケースで終局時は曲げ破壊に至っている．また， 全載荷荷重と支間中央部たわみを図-29 に示す。最大荷 重に関して，継手構造 B (CASE4, CASE5) は，既往の 接合である基準試験体の重ね継手のケース（CASE1）と ほぼ同等であり，ループ継手のケース（CASE2）より大 きな耐力を有し伸び性能も十分にあることを確認した. 一方, 継手構造 A は, 鉄筋降伏後に荷重が低下した. 試験終了後に継手周辺の間詰め材を撤去したところ，写 真-5 に示すように $\mathrm{T}$ 型治具と下筋の圧接部分で鉄筋が 破断（6 本中で 1 本）しており，これが原因と考えられ る.なお，重継手のケース（CASE1）では，他のケー スに比べて中央部のたわみが小さくなっているが，これ は継手の構造上，継手区間では 2 倍の鉄筋が配置されて いるためである.

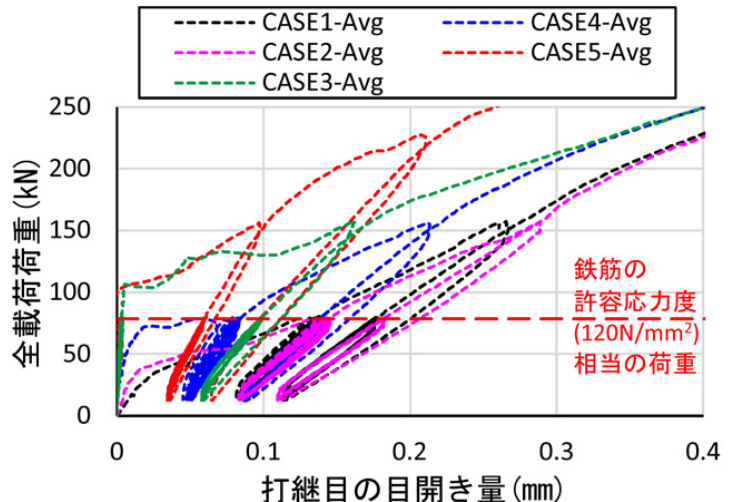

図-30 全載荷荷重-打継目の平均目開き量

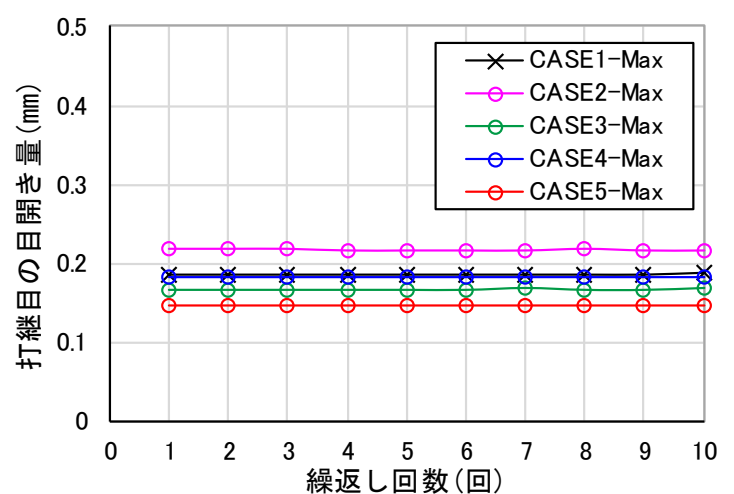

図-31 繰返し回数（ひび割れ後）-打継目の最大目開き量

\section{b) 荷重一目開き量}

全載荷荷重と PCa 部と接合部の打継目における目開 き量の関係を図-30 に示す.ここでは，試験体両側で計 4 箇所の打継目を計測したが, それらの平均目開き量を 示した．道路橋床版を想定した使用時荷重レベル（下鉄 筋の発生応力 $\left.120 \mathrm{~N} / \mathrm{mm}^{2}\right)$ では, 目開き量は, CASE2> CASE1 $>$ CASE4 $>$ CASE3 >CASE5 の順であった。重ね継 手 (CASE1) やループ継手 (CASE2) に比べ，新継手構 造（CASE3〜CASE5）の方が小さい傾向にある.これは， 重称継手やループ継手は, 継手長の部分が比較的長く, その区間で鉄筋量が 2 倍となりひび割れ分散性が悪くな るため，ひび割れが $\mathrm{PCa}$ 部との境界部である打継目付 近に集中して目開き量が大きくなる. 一方，新継手の場 合は，鉄筋量の増加もなく接合部の幅も狭いことからひ び割れが分散して打継目での目開き量が小さくなってい ると考えられる.また，ひび割れ発生後の繰返し載荷に おける最大目開き量の推移を図-31 に示す. 繰返し回数 によらずほぼ一定で安定した。

\section{c) 鉄筋ならびにコンクリートひずみ}

鉄筋ひずみゲージのうち，各ケースですべての下筋の 平均ひずみと全載荷荷重の関係を図-32 に示す。ひび割 れ発生荷重の相違はあるが，ひび割れ発生後のひずみの 挙動はほぼ同じである。若干，CASE5（継手構造 B，千 鳥）のひずみの進展が遅いが，他のケースと異なり，先 端治具が部材内に配置されており，打継目から若干離れ 


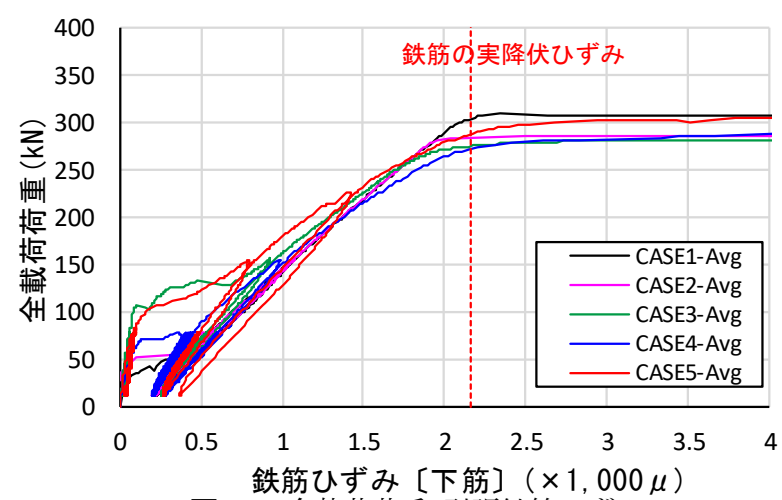

図-32 全載荷荷重-引張鉄筋ひずみ

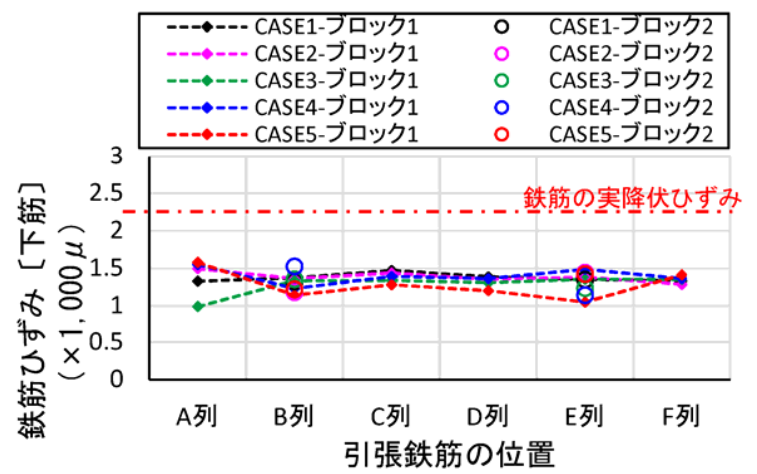

図-33＼cjkstart鉄筋位置-引張鉄筋ひずみ

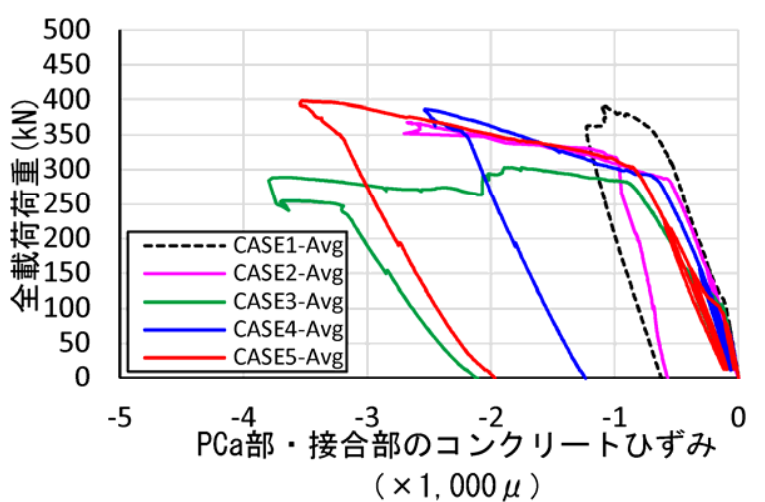

図-34 全載荷荷重-PCa部・接合部のコンクリート表面ひずみ

た位置にあるためと考えられる．また，6 本の下筋で計 測した鉄筋ひずみの幅方向でのひずみ分布（全載荷荷重 200kN 時）を図-33 に示寸. 多少のばらつきはあるが, 幅方向でほぼ均等にひずみが発生している．C 型治具の 仕様を変更し $\mathrm{C}_{2}$ 型治具を採用したことにより継手耐力 に与える側方拘束の影響は小さくなったと想定される. 次に, 全載荷荷重-PCa 部・接合部のコンクリート表面 ひずみの関係を図-34 に示す。ここでのひずみは，試験 体の上面で計測したひずみの平均值で記載している．終 局時には，打継目付近でコンクリートが圧壊しており， $3,000 \mu$ 程度のひずみで至っていることがわかる.ここに, 重ね継手（CASE1）の場合，測定位置が打継目近傍にな く支間中央のみであったこと，2 倍の配筋であることか ら計測ひずみは小さい範囲となったと考えられる.

\section{d) ひび割れ状況}

試験終了後の試験体の下面ならびに側面のひび割れ発
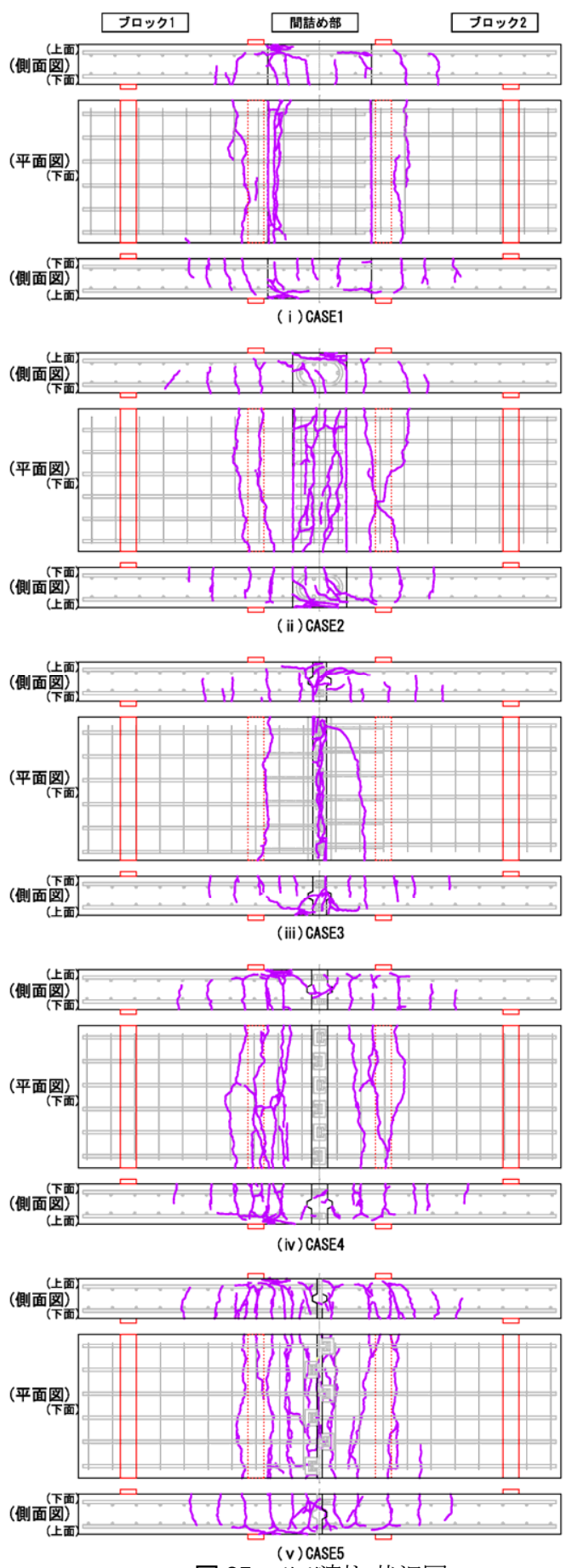

図-35 ひび割れ状況図

生状況を図-35 に示寸，なお，下面のひび割れのうち， 両側面付近の局所的なものは省略した．CASE1（重齐継 手）では，接合部に 2 倍の鉄筋が配筋されており，接合 部端部から一般部に大きなひび割れが発生した. CASE2 (ループ継手) では，接合部内でのひび割れの進展が顕 著であり，ひび割れの密度は一般部より高いように見え る. 継手構造 A の CASE3 は，接合部の幅が小さいが， 各継手の先端治具の中央を結ぶようにひび割れが集中的 に発生して大きく進展した. 継手構造 B の CASE4（イ モ）では，接合部ではひび割れは確認されず，一般部の 
表-13 試験ケース一覧（せん断試験）

\begin{tabular}{|c|c|c|c|c|c|}
\hline \multirow{2}{*}{$\begin{array}{l}\text { せん断試験 } \\
\text { 実験ケース } \\
\end{array}$} & \multicolumn{4}{|c|}{ 継手仕様 } & \multirow{3}{*}{$\begin{array}{l}\text { 継手 } \\
\text { 配置 } \\
\text { イモ }\end{array}$} \\
\hline & 継手形式 & \multicolumn{3}{|c|}{ 先端治具タイプ } & \\
\hline CASE1 & 継手構造A & P型 & - & P型 & \\
\hline CASE2 & 継手構造B & $\mathrm{C}_{2}$ 型 & - & T型 & イモ \\
\hline CASE3 & 継手構造B & $\mathrm{C}_{2}$ 型 & - & T型 & 千鳥 \\
\hline
\end{tabular}

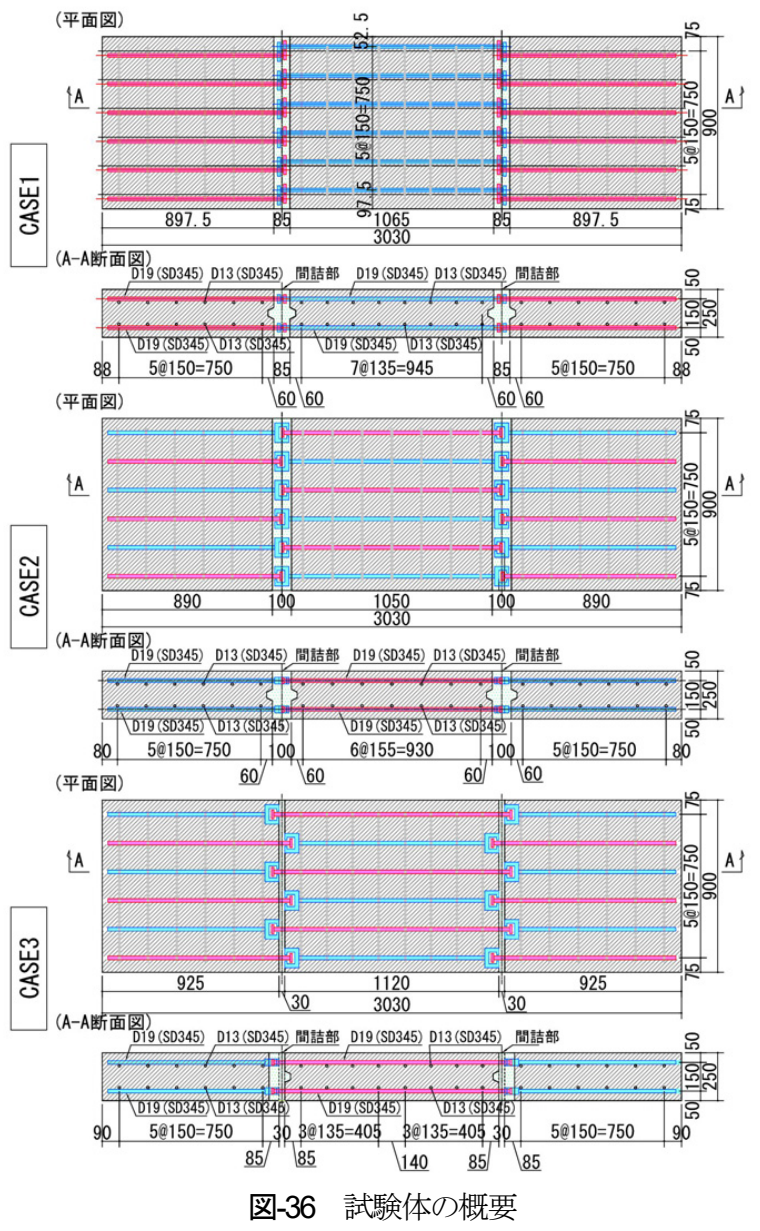

みにひび割れが分散していた。一方，CASE5（千鳥） では，一般部と接合部にひび割れ状況に大きな差異がな く，等曲げ区間で分散して発生していた。このように継 手構造 A では終局時に接合部に大きなひび割れが集中 して発生したが，継手構造 B では，接合部が一般部に 対してひび割れが集中する等の傾向は見られなかった.

\section{5. 静的せん断載荷試験}

次に，新継手構造におけるせん断性能を静的載荷試験 により確認した，道路橋示方書では，道路橋床版を検討 する場合，規定される最小床版厚を満足していればせん 断力に対する照査を省略できる 17),18).しかしながら，新 継手構造は間詰め材を介した鉄筋継手であること，特に 接合構造 B においては，継手部の上下方向（面外方 向）へのずれは間詰め材の拘束以外では物理的な拘束が ないことを踏まえ, せん断性能を確認することとした.

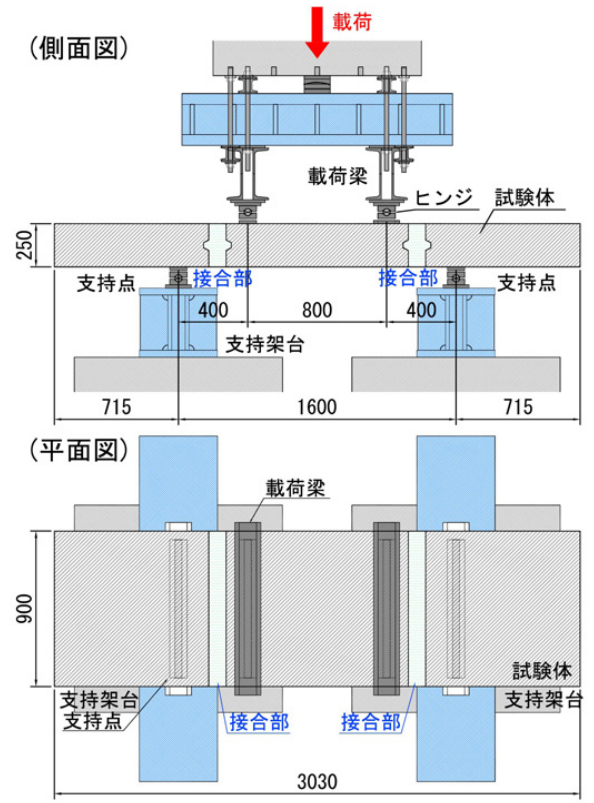

図-37 載荷装置

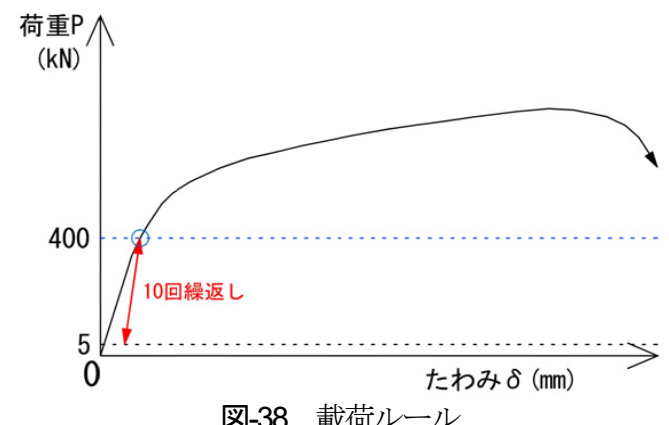

(1) 試験ケース

試験ケースを表-13 に示す。ここでは，新継手構造 2 種類と継手配置（イモ，千鳥）を考慮した計 3 ケースを 実施した。

\section{(2) 試験体の概要}

試験体の外形寸法は，軸方向 3,030mm，軸直角方向 $900 \mathrm{~mm}$, 高さ $250 \mathrm{~mm}$ とした. 2 面せん断試験を念頭にお き，軸方向に接合部を 2 箇所設けた。また，打継目には， 深さ $30 \mathrm{~mm}$ の凹のせん断キーを設け，打継ぎ処理を施し た. 試験体の製作方法は，静的曲げ試験と同様とした. 試験体の概要を図-36に示す.

\section{(3) 使用材料}

使用材料に関しては，静的曲げ試験と同様であり，材 料特性は，表-9〜表-11に示すとおりである.

\section{（4）載荷方法}

\section{a) 載荷装置}

試験は載荷能力 $10 \mathrm{MN}$ 試験機を用いて載荷した。試験 装置の概要を図-37 に示す。支持点間隔を $1,600 \mathrm{~mm}$ ，載 荷点間距離を $800 \mathrm{~mm}$ とした $(\mathrm{a} / \mathrm{d}=2.0)$. 載荷点ならび 


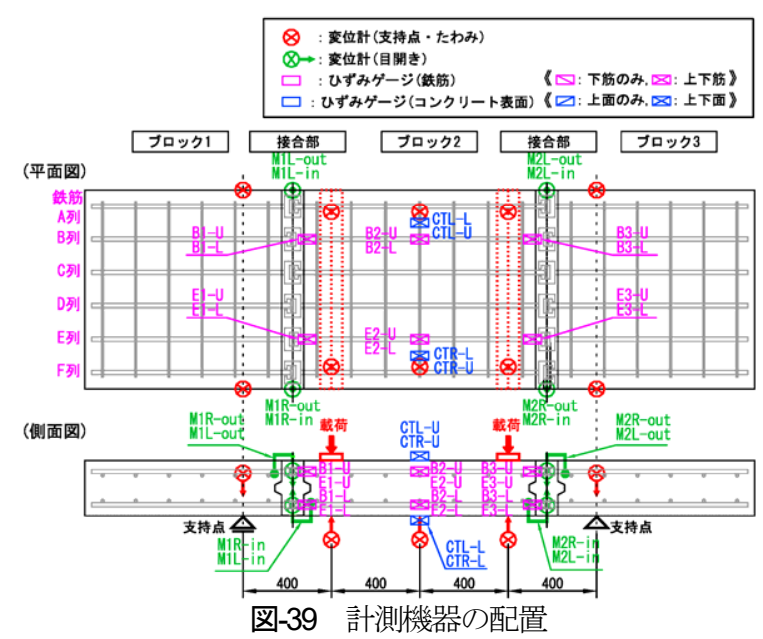

に支持点の 4 箇所のうち，載荷点の片側をピンとし，そ れ以外の 3 箇所はピンローラーとした.

\section{b) 載荷方法}

載荷は，使用時荷重レベルで 10 回繰返すこととした。 使用時荷重は，道路橋床版の輪荷重（100kN）を基本と して衝撃係数等を考慮した場合, 最大でも $150 \mathrm{kN}$ 程度と 考えられる. しかしながら，本実験では，接合部にせん 断ひび割れを発生させることを目的として 1 面あたり $200 \mathrm{kN}$ ，全載荷荷重で $400 \mathrm{kN}$ を載荷することとした．な お，輪荷重を想定した場合のせん断の有効幅として，載 荷幅十有効高さ $\times 2$ 倍を考慮すれば，約 $900 \mathrm{~mm}$ であり試 験体幅と同等である，載荷ルールを図-38に示す.

\section{(5) 計測}

計測は，載荷荷重のほか，試験体のたわみ，打継目の ずれ量，鉄筋ならびにコンクリート表面のひずみとした. 計測箇所を図-39に示す.

\section{（6）静的せん断載荷試験の結果}

\section{a) 破壊形式ならびに荷重一たわみ}

破壊形式ならびに最大荷重を表-14 に示す．また，全 載荷荷重と支間中央部たわみを図-40に示す.

継手構造 A（CASE1）では，鉄筋降伏後に接合部がせ 儿断破壊に至ったためせん断耐力は確認できたが，継手 構造 B （CASE2 および CASE3）では，せん断破壊に至 る前に等曲げ区間の PCa 部材で曲げ破壊が先行したた め，せん断耐力は確認できなかった．写真-6 に継手構 造Aにおけるせん断ひび割れの状況を示す.

一般的に梁部材のせん断而力の予測式は，二羽らによ り提案されている 1920).これらは，せん断スパン比によ りディープビーム $(\mathrm{a} / \mathrm{d}<2)$ ， スレンダービーム $(2.6 \leqq$ $\mathrm{a} / \mathrm{d} \leqq 8.6 ）$ の構造を区別した回帰式である.これらの式 に基いてせん断耐力を算出すると, ディープビームの回 帰式 : 786(kN), スレンダービームの回帰式 : 317(kN)で
表-14 破壊状況一覧

\begin{tabular}{|c|c|c|c|}
\hline $\begin{array}{c}\text { せん断試験 } \\
\text { 実験ケース }\end{array}$ & $\begin{array}{c}\text { 全載荷荷重 } \\
\operatorname{Max}(\mathrm{kN})\end{array}$ & $\begin{array}{c}\text { 最大荷重 } \\
\operatorname{Max}(\mathrm{kN}) \\
\text { 〔接合部あたり〕 }\end{array}$ \\
\hline \hline CASE1 & 鉄筋曲げ降伏後のせん断破壊 & 765 & 382.5 \\
\hline CASE2 & 曲げ破壊 & 782 & 391 \\
\hline CASE3 & 曲げ破壊 & 804 & 402 \\
\hline
\end{tabular}

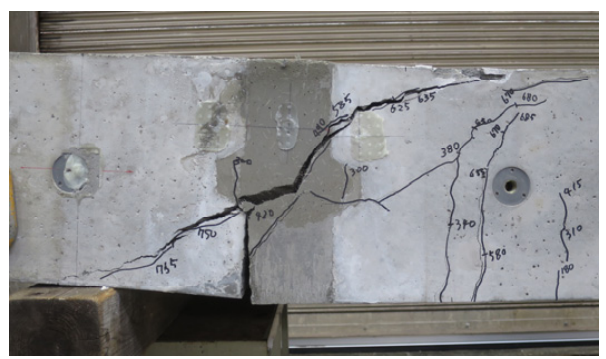

写真-6 せん断ひび割れ (CASE1)

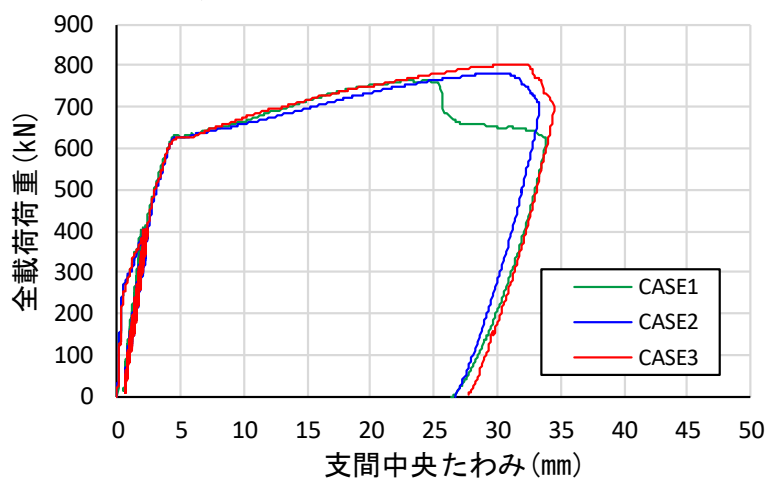

図-40 全載荷荷重-支間中央たわみ

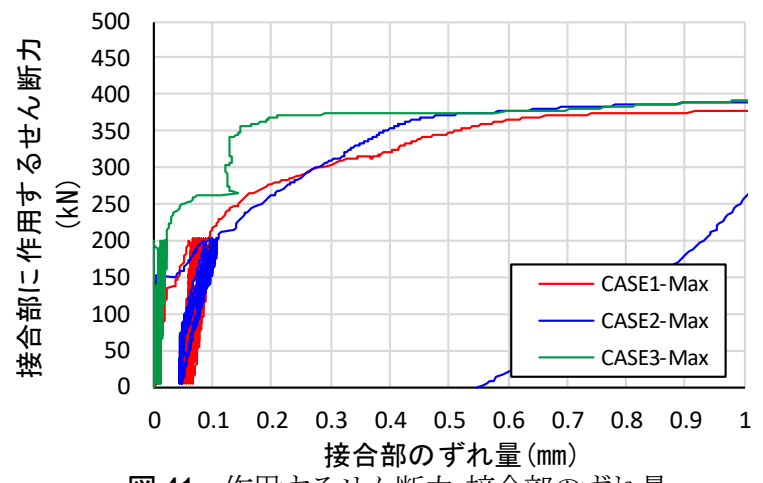

図-41 作用するせん断力-接合部のずれ量

あった. 新継手構造を有する部位のせん断耐力の予測は 困難であるが，本試験のせん断スパン比は 2.0 であり， 両回帰式におけるせん断スパン比の設定值の間にあるこ とから，せん断耐力は前述の両回帰式による算定值の間 と想定された. 表-14 の結果から，せん断耐力はすべて のケースにおいて少なくともスレンダービームの算定值 以上であることは確認できた，前述のように，道路橋床 版を考える場合は，接合部単位幅あたりに作用するせん 断力（最大 $150 \mathrm{kN}$ と想定）に対し 2.5 倍以上の安全率を 確保できている.このため, せん断破壊は発生しないと 考えられる.

\section{b) 荷重-ずれ量}

接合部 1 箇所あたりに作用するせん断力と接合部のず れ量を図-41 に示す，ただし，ここでのずれ量は，1つ 


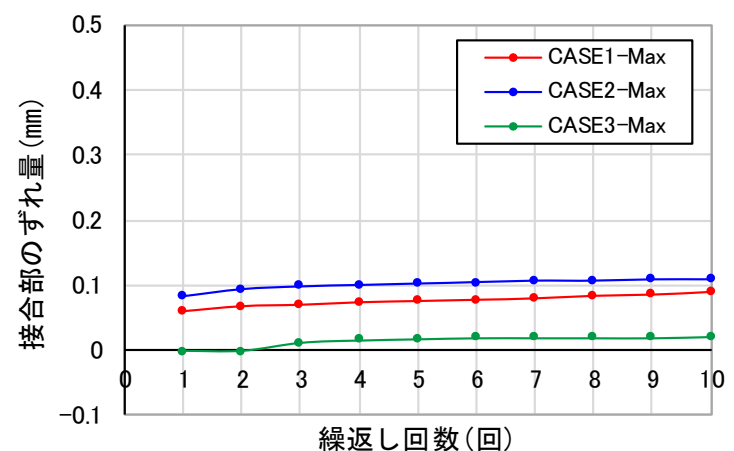

図-42 繰返し回数と接合部のずれ量の推移

の接合部（打継目 2箇所の合計）を示している. また，

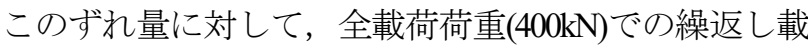
荷時の推移を図-42 に示す. 本試験では作用せん断力が 想定される最大せん断力 $150 \mathrm{kN}$ より大きな $200 \mathrm{kN}$ となる ように静的載荷を行っている. このような条件で 10 回 の繰り返し載荷の結果でも，接合部のずれ量は $0.1 \mathrm{~mm}$ 程度と小さく, また，ほとんど増加がなく推移した。

\section{6. まとめ}

本研究により得られた主な知見を，各試験に対し継手 構造ごとに整理した結果を以下に示す。

\section{(1) 継手単体の引張試験}

\section{a) 継手構造 $A$}

側方拘束の作用や接合部の間詰め材の繊維補強が継手 の引張耐力の向上に効果があることを確認した．側方拘 束があり，かつ間詰め材に補強䋊維を混入した場合は， 鉄筋の規格降伏強度以上の耐力は確保できた。

継手構造 A では対向する鉄筋配置が偏心しているた め，終局時は，先端治具（P 型）と鉄筋の圧接近傍で鉄 筋に曲げが卓越し破断した。.また，載荷過程において， 先端治具 $(\mathrm{P}$ 型) よりも上述の圧接近傍の鉄筋で先行し て降伏に至っているため，P 型の仕様を見直しても継手 耐力の向上には効果が小さいと考えられる.

\section{b) 継手構造 B}

継手構造 $\mathrm{A}$ と同様に側方拘束の作用や接合部の間詰 め材の繊維補強が継手の引張而力の向上に効果があるこ とを確認した.

$\mathrm{C}_{1}$ 型治具を用いた場合（シリーズ 1）は，終局時には $\mathrm{C}_{1}$ 型の変形が進展し, $\mathrm{T}$ 型治具が抜け出して破壊した.

一方， $\mathrm{C}_{2}$ 型治具を用いた場合（シリーズ2）は， $\mathrm{C}_{2}$ 型の 変形が小さく引張耐力が上昇した. その結果, シリーズ $2\left(\mathrm{C}_{2}\right.$ 型治具 $)$ で，側方拘束が作用し，かつ，間詰め材 の補強䋊維に鋼繊維（繊維長 $6 \mathrm{~mm}$, 混入率 $1.5 \mathrm{vol} \%$ も くは繊維長 $9 \mathrm{~mm}$ ，混入率 $1.0 \mathrm{vol} \%$ ）を混入すると鉄筋の
規格引張強度と同等の引張而力を磼認できた。

継手の配置（イモもしくは千鳥）による有意な差は確 認できなかった.

\section{(2)＼cjkstart静的曲げ試験}

\section{a) 継手構造 $A$}

基準ケース（重亦継手，ループ継手）に対して曲げ耐 力は小さく, 重ね継手に対して 77\%程度であった. 終 局時は下筋 6 本の内, 端部の 1 本で先端治具（P 型）と 鉄筋の圧接部近傍の鉄筋が破断した。 継手単体の引張試 験の破壊状態と同様であり，鉄筋配置の偏心の影響と端 部鉄筋の側方拘束が小さいことに起因寸ると考えられる.

\section{b) 継手構造 B}

曲げ耐力は，継手の配置によらず，基準ケース（重称 継手ならびにループ継手）と同等であることを確認でき た. また，打継目の目開き量は，使用荷重レベルで基準 ケースと同等か若干小さい傾向であった。

下筋の鉄筋ひずみ $1,500 \mu$ （全載荷荷重 $200 \mathrm{kN}$ ） レベル では，幅方向での中央付近と端部での鉄筋ひずみの差が 確認されず， $\mathrm{C}_{2}$ 型治具の仕様を上げたこともあり側方 拘束の差異による影響が小さくなったと考えられる.

ひび割れ発生状況は，イモ配置の場合は接合部にほと んじ発生せず一般部のみに分散した。一方，千鳥配置の 場合は接合部を含め等曲げ区間全体に均等に発生した.

\section{(3) 静的せん断試験}

\section{a) 継手構造 $A$}

せん断耐力は，道路橋床版を想定した場合は，安全率 を 2.5 程度は確保できた。

接合部 1 箇所あたりのずれ量は，接合部に作用するせ ん断力を $200 \mathrm{kN}$ として実施した繰返し載荷時で， $0.1 \mathrm{~mm}$ 程度と小さい範囲で推移した.

\section{b) 継手構造 B}

継手配置がイモ配置と千鳥配置での傾向はほぼ同様で あった。、ずれも最終的な破壊状態が曲げ破壊であった ため，せん断耐力は確認できなかった，しかしながら， 曲げ破壊に至った最大荷重時において接合部 1 箇所に作 用するせん断力でも，道路橋床版を想定した場合に作用 するせん断力に対して, 安全率を 2.5 程度は確保できた

1 箇所あたりのずれ量は，作用せん断力が $200 \mathrm{kN}$ 程度 でも $0.1 \mathrm{~mm}$ 程度の小さい範囲で推移した.

以上のことから，継手構造 A では，対向寸る鉄筋の 偏心配置が継手単体の引張耐力や床版等の曲げ耐力に及 ぼす影響が大きく, 道路橋床版の要求性能を達成するこ とは困難と判断できる. 一方, 継手構造 B は, 継手単 体での引張而力が鉄筋の規格引張強度以上であり，また， 床版構造でも曲げ，せん断挙動に対して既往の継手と同 等以上の耐力を確保できる仕様を選定できたため，静 
的試験のレベルでは $\mathrm{PCa}$ 部材間の継手構造としての適 用性を確認できた。

今後の展望として，継手構造 B に対象を絞り $\mathrm{PCa}$ 道 路橋床版の接合部への適用検討を進めることとし，輪荷 重走行試験による而疲労性の評価を行うとともに，実物 大 PCa 床版を製作し，床版設置時の据付効率，継手部 の嵌合状態, 間詰め部のモルタル充てん性等の施工性に ついて実証試験を行う予定である.

謝辞 : 本研究は, 内閣府総合科学技術・イノベーション 会議の「SIP インフラ維持管理・更新・マネジメント技 術」（管理法人：JST）の「道路インフラマネジメント サイクルの展開と国内外への実装を目指した統括的研 究」(研究代表者: 前川宏一) の一環として行われたも のである。ここに記して関係者に謝意を表します。

\section{参考文献}

1) 国土交通省：国土交通白書 平成 28 年度, pp. 55-58, 2017.

2) 市村靖光, 高野進, 笹川隆介, 古本一司 : コンクリ ート工の生産性向上のためのプレキャスト化の推進 について, 第 34 回建設マネジメント問題に関する研 究発表・討論会講演集, pp. 85-88, 2016.

3) 土木学会 : コンクリート標準示方書 2012 年制定, pp. 330-349, 2012.

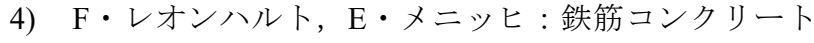
の配筋，pp. 68-70, 1985.

5) 中村定明, 三浦尚 : RC ループ継手の力学挙動に関す る基礎的研究, 土木学会論文集, No. 774/V-65, pp. 17-26, 2004.

6) 大信田秀治, 横田正幸, 仁井谷教治, 中川宏希 : エ ンドバンド鉄筋を用いた新しい連結桁の設計・施工, プレストレストコンクリート技術協会 第 19 回シンポ ジウム論文集，pp. 5-8, 2010.

7) 吉松秀和, 松井繁之, 大澤浩二, 中山良直, 水野浩, 表真也：床版取替え用プレキャスト PC 床版の合理化 継手の開発, 土木学会 構造工学論文集, Vol. 60A, pp.
1159-1168, 2014.

8) 土木学会 : 鉄筋定着・継手指針[2007 年版], コンク リートライブラリー128, 2007.

9) 塩谷由明, 蓑田理希, 久保田五十一, 森孝臣: コッ タージョイントを用いた架け替え用プレキャスト床 版の検討, 土木学会第 59 回年次学術講演会, pp. 1473-1474, 2004.

10) 渡邊輝康，浅見恭輔：コッター式継手を有する橋梁 用床版（コッター床版）の性能確認試験（その 1）, 土木学会第 72 回年次学術講演会, pp. 601-602, 2017.

11）宮川隆良, 渡邊輝康, 松本政徳：コッター式継手を 有する橋梁用床版（コッター床版）の性能確認試験 (その 2), 土木学会第 72 回年次学術講演会, pp. 603-604, 2017.

12）日本道路協会：道路橋示方書 - 同解説（鋼橋編）, pp. 276-277, 2012.

13）東日本高速道路株式会社，中日本高速道路株式会社， 西日本高速道路株式会社 : 設計要領 第二集 建設橋梁 編, pp. 7-36 7-38, 2015.

14）壹岐直之, 清宮理 : 静的繰り返し載荷が異形鉄筋の 付着特性に及ぼす影響, コンクリート工学年次論文 集, Vol. 22, No. 3, pp. 1195-1200, 2000.

15) 麻生高行, 金久保利之：繰返し荷重下における鉄筋 コンクリートの付着性状に関する研究, コンクリー 卜工学年次論文集, Vol. 32, No. 2, pp. 589-594, 2010.

16) 三木朋宏, 塩見拓也: 繰返し荷重を受ける腐食した 鉄筋の付着挙動に関する研究, コンクリート工学年 次論文集, Vol. 35, No. 2, pp. 601-606, 2013.

17) 日本道路協会：道路橋示方書 - 同解説（鋼橋編）, pp. 264-274, 2012.

18）日本道路協会：道路橋示方書・同解説（鋼橋編）, pp. 283-288, 2012.

19) 二羽淳一郎, 前田詔一, 岡村甫 : ディープビーム的 な $\mathrm{RC}$ 部材の設計方法に関する提案, 第 5 回コンクリ 一下工学年次講演論文集, 1983, pp. 358-360, 1983.

20) 二羽淳一郎, 山田一宇, 横沢和夫, 岡村甫 : せん断 補強鉄筋を用いない RC はりのせん断強度式の再評価, 土木学会論文集, No. 372/V-5, pp. 167-176, 1986.

(2017. 10. 4 受付)

\section{EXPERIMENTAL STUDY ON LOAD-CARRYING CAPACITY OF NEW REBAR CONNECTION SYSTEM BETWEEN PRECAST CONCRETE MEMBERS}

\section{Takeshi KITAMURA, Weijian ZHAO, Manabu HOSOTANI and Ichiro IWAKI}

When precast concrete structure is constructed, it may be concerned that the joint work takes much time and causes structural weaknesses. Therefore, in this study, two types of new rebar connection systems between precast members were proposed. These connections have special tools attached in the tops of rebars which protrude from adjacent precast members, and the whole of these tools and around it are combined by high performance mortar after their members are connected. This paper described the load carrying capacities with proposed joints by experimental approaches, such as tension test for the specimen extracting a pair of connection, and static load test for the specimen with joints modeling precast road bridge deck slab. These results revealed that one of new connection systems had sufficient load bearing performance. 